\title{
Liquefaction structures induced by the M5.7 earthquake on May 28, 2018 in Songyuan, Jilin Province, NE China and research implication
}

\author{
Zhu-Fu Shao ${ }^{1,2,3^{*}}$ (D) Jian-Hua Zhong ${ }^{4}$, John Howell33, Bing Hao ${ }^{4}$, Xi-Wu Luan ${ }^{5}$, Ze-Xuan Liu', Wei-Min Ran', \\ Yun-Feng Zhang ${ }^{1}$, Hong-Qi Yuan ${ }^{1}$, Jing-Jing Liu', Liang-Tian Ni ${ }^{4}$, Guan-Xian Song ${ }^{4}$, Jin-Lin Liu', \\ Wen-Xin Zhang ${ }^{1}$ and Bing Zhao ${ }^{1}$
}

\begin{abstract}
An earthquake of magnitude M5.7 occurred in Yamutu village, Songyuan City, Jilin Province, NE China $\left(45^{\circ} 16^{\prime \prime} 12^{\prime \prime} \mathrm{N} /\right.$ $\left.124^{\circ} 42^{\prime} 35^{\prime \prime} \mathrm{E}\right)$ on May 28, 2018, with a focal depth of $13 \mathrm{~km}$. The epicenter is located at the intersection of the Fuyu/ Songyuan-Zhaodong Fault, Second Songhua River Fault and Fuyu North Fault which lies northwest of TanchengLujiang Fault (Tan-Lu Fault). The earthquake-induced widespread liquefaction structures and ground surface fissures within $3 \mathrm{~km}$ from the epicenter, caused serious disasters to the local surroundings. The visible liquefied structures include sand volcanoes, liquefied sand mounds, sand dikes and sand sills. Sand volcanoes can be divided into sand volcano with a crater, sand volcano without a crater and water volcano (no sand). Other soft-sediment deformation structures (SSDS) induced by the earthquake include deformation lamination, load and flame structures, deformation folds, dish structures, convolute bedding and water-escape structures. The formation process of the sand volcanoes comprises three stages: (1) building up excess pore-fluid pressure in the liquefied layer, (2) cracking of the low-permeable overlying layer, and (3) mixture of sand-water venting out of the ground surface. During the upward movement, the liquefied sand is injected into the low-permeable layer to form sand veins, sand sills and various types of deformation structures. Vertical distribution of seismic liquefaction structure can be divided into four zones: the thoroughly liquefied zone, the lower liquefied zone with SSDS, the upper liquefied zone with SSDS, and the ground surface liquefied zone. The liquefaction occurred at a burial depth of 2-5 $\mathrm{m}$, and the thickness of liquefied sand is $2 \mathrm{~m}$. NE-SW $\left(35^{\circ}-215^{\circ}\right)$ trending compressive stress is possibly the seismogenic trigger of the Songyuan M5.7 earthquake that caused the fault (Fuyu/Songyuan-Zhaodong Fault) to reactivate. The study of the Songyuan seismic liquefaction structures gives insight into the prediction of modern earthquakes and disasterprone areas. Meanwhile it provides abundant basic material for studying earthquake-induced SSDS in both ancient and modern sediments. The research is obviously of great significance to reveal that the northern Tan-Lu Fault has entered a stage of active seismic activity since the twenty-first century.
\end{abstract}

Keywords: Earthquake, Soft-sediment deformation structures, Liquefaction structure, Sand volcano, Songyuan

\footnotetext{
*Correspondence: kangzhu09@yeah.net

${ }^{1}$ School of Geosciences, Northeast Petroleum University, Daqing 163318, Heilongjiang Province, China

${ }^{2}$ Shandong Provincial Key Laboratory of Depositional Mineralization and Sedimentary Mineral, Shandong University of Science and Technology, Qingdao 266590, Shandong Province, China

Full list of author information is available at the end of the article
} 


\section{Introduction}

The formation of SSDS depends on three aspects: the susceptibility of unconsolidated sediment to liquidization, the triggers that change the physical state of sediment with low yield strength, and a sufficient amount of force (Allen 1986). The deformation mechanism varies with the properties of the materials. For elastic and plastic sediments, a large enough stress that exceeds the yield strength can lead to deformation. For viscous materials, liquefaction is the main deformation mechanism. Viscous materials are easily deformed because of their high thixotropy and sensitivity to liquefaction and fluidization (Owen 1987). Shanmugam (2016) pointed out that there are at least 21 triggers causing softsediment deformation structures, including short-term events, intermediate-term events and long-term events, among which, earthquakes were believed to be the most important trigger for the formation of SSDS.

Liquefaction structures are one kind of common SSDS (Shanmugam 2017). It includes sand dikes, sand veins, sand pillars, sand (mud) volcanoes (sand boils), sand tubes (sand pipes), sand blow, sandcusps, deformation folds, deformation lamination, load structure, dish structure, convolute bedding, diapirs, draw-in structure, pseudonodules and other water-escape structures (Lowe and LoPiccolo 1974; Lowe 1975, 1976; Allen 1977, 1982; Owen 1987, 1995; Obermeier 1996; Rodríguez-Pascua et al. 2000; Takahama et al. 2000; Massari et al. 2001; Tuttle 2001; Kholodov 2002; Lu et al. 2006; Glennie and Hurst 2007; Moretti and Sabato 2007; Bonini 2009; Chen et al. 2009; Gibert et al. 2011; Owen and Moretti 2011; Owen et al. 2011; Ross et al. 2011; Rowe 2013; Su et al. 2014; Valente et al. 2014; Yi et al. 2015; Mazumder et al. 2016; Oppo and Capozzi 2016; Ulvrova et al. 2016; Du and Yu 2017; Hurst and Vigorito 2017; Zhong et al. 2018). Liquefaction can even trigger a giant sand injection complex (Satur and Hurst 2007; Grippa et al. 2019; Su et al. 2019).

Liquefaction can be distinguished into the three types of static, impulsive and cyclic (Owen 1987), which can occur in environments such as glaciers, deserts, intermountain depressions, rivers, deltas, tidal zones, continental slopes and submarine fans (Kuribayashi and Tatsuoka 1975; Alfaro et al. 1997; Moretti e al. 2001; Moretti and Sabato 2007; Shi et al. 2007; van Loon 2009; Alfaro et al. 2010; Moretti and Ronchi 2011; van Loon and Maulik 2011; Phillips et al. 2013; Owen and Santos 2014; Ravier et al. 2015; Koç-Taşgın and Diniz-Akarca 2018; Zhong et al. 2018), but mainly in lakes and oceans. Some authors reported the possibility of liquefaction on Mars (Mahaney et al. 2004; Wang et al. 2005). Liquefaction occurs mostly in clastic and carbonate sediments (Su et al. 2014) and in bedrock (Friese et al. 2011). Earthquakes, volcanic eruptions, meteorite impacts, tsunamis and storm waves, depositional loading, thawing of ice-rich frozen soils, glacier melting, tides, flooding, slide and slump, turbidite, piping and diversion of runoff, groundwater movement, sea level changes, diapirism, gas leaks, digenesis and biological activities can trigger liquefaction (Burne 1970; Allen and Banks 1972; Owen 1987; Obermeier 1996; Harris et al. 2000; Murton et al. 2000; Moretti et al. 2001; Mahaney et al. 2004; Mazumder et al. 2006, 2016; Zhong et al. 2006, 2008, 2018; Glennie and Hurst 2007; Greb and Archer 2007; Owen and Moretti 2008, 2011; Mei et al. 2009; van Loon 2009; Zhong and Liang 2009; Alfaro et al. 2010; Owen et al. 2011; Chen and Lee 2013; Li et al. 2013; Miyakawa et al. 2013; Phillips et al. 2013; Rowe 2013; Tian et al. 2014; Owen and Santos 2014; Shao et al. 2014a; Ravier et al. 2015; Ulvrova et al. 2016; Capaccioni et al. 2017; Du and Yu 2017; Feng 2017; Feng et al. 2017; Hurst and Vigorito 2017; Ko et al. 2017; Koç-Taşgın and DinizAkarca 2018).

Earthquakes are one of the most important triggers leading to liquefaction and fluidization. During an earthquake, unconsolidated saturated sediments are affected by the seismic shear waves and the internal texture is rearranged, thus forming viscous fluids with no yield strength. Then effective stress transferring caused by liquefaction leads to excessive intergranlar pore-fluid pressure which can last for seconds. Clastic particles redeposit after transitory seismic liquefaction (Allen 1982; Owen 1987; Obermeier 1996; Obermeier and Pond 1999; Tuttle 2001; Owen and Moretti 2011). Pore-fluid pressure gradually increases due to cyclical seismic shock and then exceeds the overburden pressure or fracturing pressure, resulting in pressure release and fluidization. Various deformation structures occur because of the movement of water and sand (Obermeier 1996; Owen et al. 2011; Shao et al. 2014a, 2014b, 2014c).

The liquefaction intensity is related to the magnitude, distance of the epicenter, focal depth and duration of earthquakes, and is influenced by the grain size, thickness, degree of consolidation of the liquefiable sand layer and the thickness of the overlying low-permeable layer (Burne 1970; Obermeier 1996; Moretti et al. 1999; Valente et al. 2014).

Liquefaction occurs most easily in fine and coarse sand (Owen and Moretti 2011) but has also been reported in sandy conglomerate (Takahama et al. 2000). Generally, the minimum earthquake magnitude causing liquefaction is M5-6 (Yang 1985; Allen 1986; Obermeier and Pond 1999; Ko et al. 2017), and most of the liquefaction occurs at a depth of less than $5 \mathrm{~m}$ (Obermeier 1996; Rodríguez-Pascua et al. 2000; Owen et al. 2011; Berra and Felletti 2011; Zhao 2012; Wei et al. 2016).

An earthquake of M5.7 occurred in Yamutu village, Songyuan City of Northeast China $\left(45^{\circ} 16^{\prime} 12^{\prime \prime}\right.$ N $/ 124^{\circ} 42^{\prime}$ $35^{\prime \prime E}$ ) on May 28, 2018, with a focal depth of $13 \mathrm{~km}$, followed by a series of M2-3 aftershocks in the 
following days. Liquefaction and fluidization induced by the earthquake distributed in a range of $3 \mathrm{~km}$ and the most common type is sand volcano. In this paper, the types, their relations and spatial distribution of liquefaction structures are introduced in detail, and their generation mechanism is illustrated to provide materials for seismic researches of ancient time and modern time as well.

\section{Results}

Lots of sand volcanoes and other liquefaction structures were found which were induced by the Songyuan M5.7 earthquake that happened on May 28, 2018 within $3 \mathrm{~km}$ from the epicenter. Sand volcanoes, sand mounds, sand dike, and sand sill were the most common and main seismic liquefaction structures. Sand volcanoes can be divided into three types according to their morphologies and structures: sand volcano with a crater, sand volcano without a crater, and water volcano (no sand). Vertically, the liquefaction structure distribution of the M5.7 earthquake in Songyuan has obvious stratification, which can be divided into 4 zones: the thoroughly liquefied zone, the lower liquefied zone with SSDS, the upper liquefied zone with SSDS, and the ground surface liquefied zone. From the characteristics of ground fissures and liquefaction structures, it is inferred that the Fuyu/SongyuanZhaodong Fault, which is part of the northern Tan-Lu Fault, was the major seismogenic fault. Therefore, the Songyuan M5.7 earthquake reveals that the northern Tan-Lu Fault has entered a stage of active seismic activity since the twenty-first century.

\section{Geological setting}

Songyuan is located in the northwest of Jilin Province and geomorphologically belongs to the Songnen Plain area and tectonically is in the central depression zone of the Songliao Basin, west of Northern Tan-Lu Fault. The Songliao Basin was a Meso-Cenozoic continental polycyclic superimposed basin sandwiched by the North China Plate, the Siberian Plate and the Pacific Plate(Ge et al. 2010; Meng et al. 2012; Wang et al. 2015b; Han et al. 2018), with the Nenjiang-Kailu Fault and the Daxing'anling Orogen to the west, the Yilan-Yitong Fault and the Zhangguangcailing Orogen to the east, the Nemor River Fault and the Xiaoxing'anling Orogen to the north, and the Chifeng-Kaiyuan Fault and the Yanshan Orogen to the south (Fig. 1). The tectonostratigraphic units of the NNE trending basin are featured by block fault, interior sag and structural inversion, filling with clastic and volcanic deposits. The direction of the fault in the basin is mainly NNE-NE and NNW-NW (Zhang et al. 1997; He et al. 2011).

Faults around Songyuan are frequently active (Fig. 2), among which the most important are Fuyu/Songyuan-
Zhaodong Fault, Second Songhua River Fault, Fuyu North Fault, Gudian Fault, and Chaganhua-Daozijing Fault (Yang et al. 2010; Shao et al. 2015; Xue et al. 2015; Liu et al. 2017b; Pan et al. 2018). These faults are decribed below.

1) Fuyu/Songyuan-Zhaodong Fault. Starting from Zhaodong in the north and ending at Huaide in the south, the early-middle Pleistocene active Fuyu/ Songyuan-Zhaodong Fault is the boundary of the central sag and south-east uplift, striking NE, inclining SE and dipping $70^{\circ}-80^{\circ}$ (Liu et al. 2017b; Pan et al. 2018).

2) Second Songhua River Fault. It was active during early-middle Pleistocene period starting from Da'an in the west and ending at Chongshan in the east with a length of more than $500 \mathrm{~km}$, striking NW, inclining NE, dipping $70^{\circ}-80^{\circ}$ (Yang et al. 2010).

3) Fuyu North Fault. A branch fault of the FuyuZhaodong Fault. This 30-km-long fault has been active since the Holocene with striking EW, inclining S, dipping $70^{\circ}-80^{\circ}$ (Liu et al. 2017b).

4) Gudian Fault. A branch fault of the Fuyu-Zhaodong Fault. This $60-\mathrm{km}$-long fault has been active since the Holocene with striking NW-SW, inclining NESE (Shao et al. 2015; Liu et al. 2017b).

5) Chaganhua-Daozijing Fault. The southern branch of the Fuyu-Zhaodong Fault. This 30-km-long fault has been active since the Holocene with striking NW-SW, inclining SE-NE (Liu et al. 2017b).

Songyuan area is located in the hinterland of the Songnen Plain. The Quaternary loose sediments are 80-100 $\mathrm{m}$ thick, and mainly consist of black silt and fine sand interbedded deposits. The succession from bottom to top is Lower Holocene Wenquanhe Formation, Middle Holocene Tantu Formation and Upper Holocene Guojiadian Formation, respectively (Guo et al. 2007; Zhao 2010). The burial depth of the underground water table is generally less than $5 \mathrm{~m}$ (Tian et al. 2011; Pan et al. 2018). The loose sediments on the shallow surface around Yamutu village (Guojiadian Formation) can be divided into five stratigraphic units according to the results of three drilling wells approximately $1 \mathrm{~km}$ from the epicenter (Fig. 3). From top to bottom these units are: unit 1: Black clay layer rich in humus (black soil) with a thickness of $50-70 \mathrm{~cm}$; unit 2: 45-60-cm-thick light brown silty clay; unit 3 : Orange-brown palaeoweathering crust depositional clay with a thickness of $10-15 \mathrm{~cm}$, which can be traced in the whole area; unit 4: 10-15-cm-thick light gray silty clay; unit 5: Light yellow well-sorted and rounded fine sand and siltstone with a thickness of approximately $20 \mathrm{~cm}$.

Earthquakes happened frequently in Songyuan, with up to 77 of larger than M2 since 2006, particularly after 


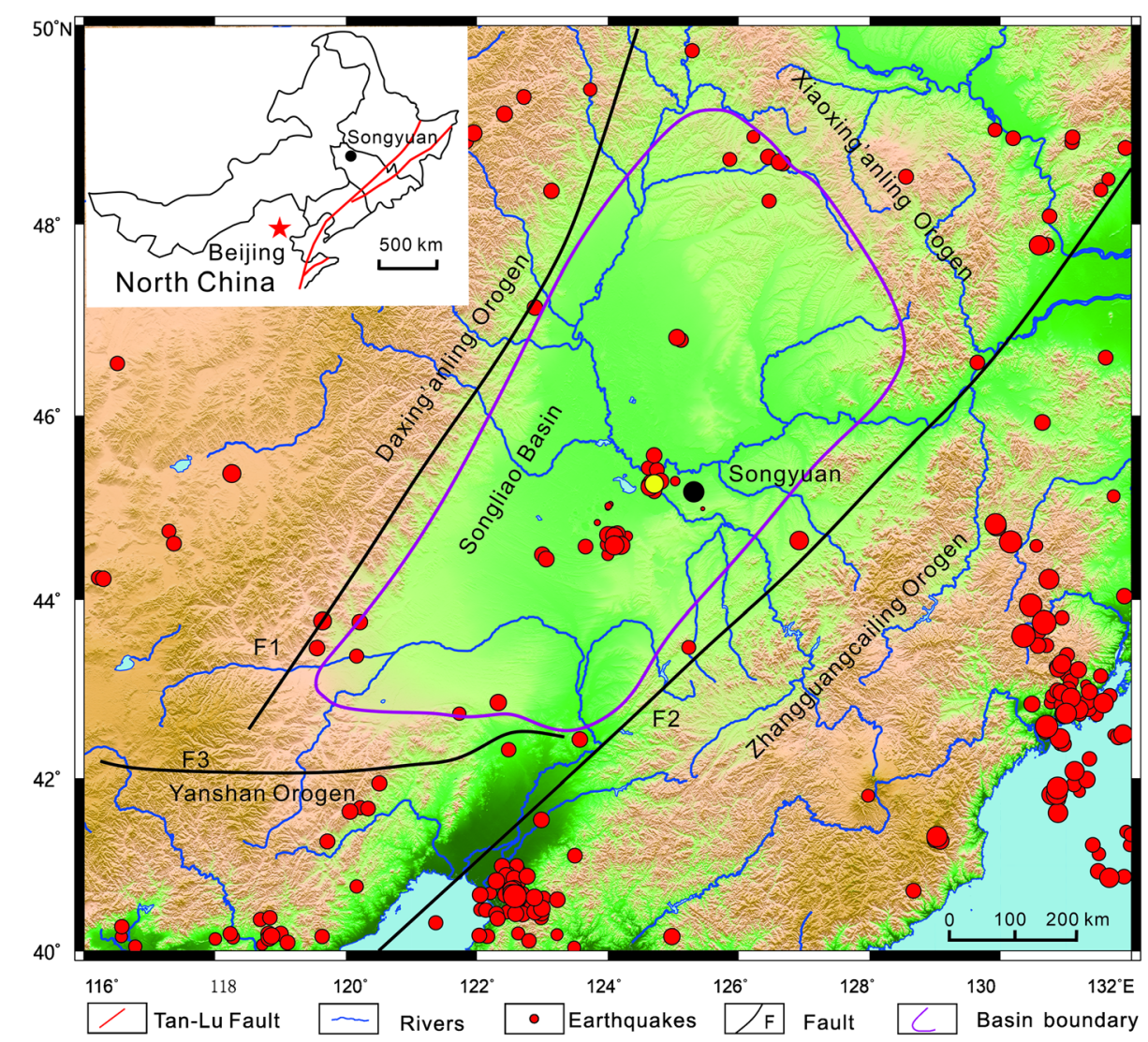

Fig. 1 Geographic and tectonic location of Songyuan (black dots), Jilin Province, NE China. F1: Nenjiang-Kailu Fault; F2: Yilan-Yitong Fault; F3: Chifeng-Kaiyuan Fault. The red dots are the epicenter of earthquakes that happened in the Songliao Basin and their surrounding area since 1976, and the yellow dot is the epicenter of the M5.7 earthquake in Yamutu village, Songyuan on May 28, 2018

2013 (Fig. 4). The largest recorded earthquake in Songyuan was the M63\%4 Qianguo earthquake in $1119 \mathrm{AD}$, with its epicenter at the intersection of the Fuyu/Songyuan-Zhaodong Fault and the Second Songhua River Fault (Wu 1991). Two M5.5 earthquake clusters occurred in Chaganhua town in Songyuan in March 2006 and October 2013, with the epicenter located at the intersection of the Gudian Fault and the ChaganpaoDaozijing Fault zone (Shao et al. 2015; Pan et al. 2018). The epicenter of the M5.7 earthquake on May 28, 2018 was located at the intersection of the Fuyu/SongyuanZhaodong Fault and the Second Songhua River Fault.

\section{Earthquake-induced liquefaction structures}

Songyuan M5.7 earthquake caused severe liquefaction of loose sediments on the surface (stratigraphic unit 5 in Fig. 3), leading to the eruption of sand volcanoes of several meters high and more than $1 \mathrm{~m}$ in diameter. During or shortly after the earthquake (within a few minutes), the excessive pore fluid pressure in the liquefied layer broke through the weight or fracture pressure of the overlying layer and poured out of the surface with sand distributing along caves or cracks. Sand volcanoes can last up to half an hour and can vent up to 6-7 $\mathrm{m}$ if the pressure is sufficiently large (Obermeier 1996). The ejected sand and mud accumulate around the crater after the eruption, forming various types of sand volcanoes, as shown in Fig. 5; more than 60 sites of sand volcanoes were found after the M5.7 earthquake within 3 $\mathrm{km}$ around the epicenter. We conclude through detailed analysis that the stratigraphic unit 5 was considered to be the main liquefied layer, and the stratigraphic units 1-4 were impermeable or low-permeable cap layers.

\subsection{Sand volcanoes}

A sand volcano, also named a sand boil (Lowe 1975; Obermeier et al. 1992; Obermeier 1996; Li et al. 1996; Moretti et al. 1999; Massari et al. 2001; Tuttle 2001; Kanıbir et al. 2006; Bhattacharya et al. 2011; Moretti and Ronchi 2011; Ross et al. 2011; Yamaguchi et al. 2012; Capaccioni et al. 2017), is the most common and dominant seismic liquefaction structure type in Songyuan. Sand volcanoes are assembled in groups and in a certain dominant direction (Fig. 5), and can be divided into three types according to their morphologies and structures. 


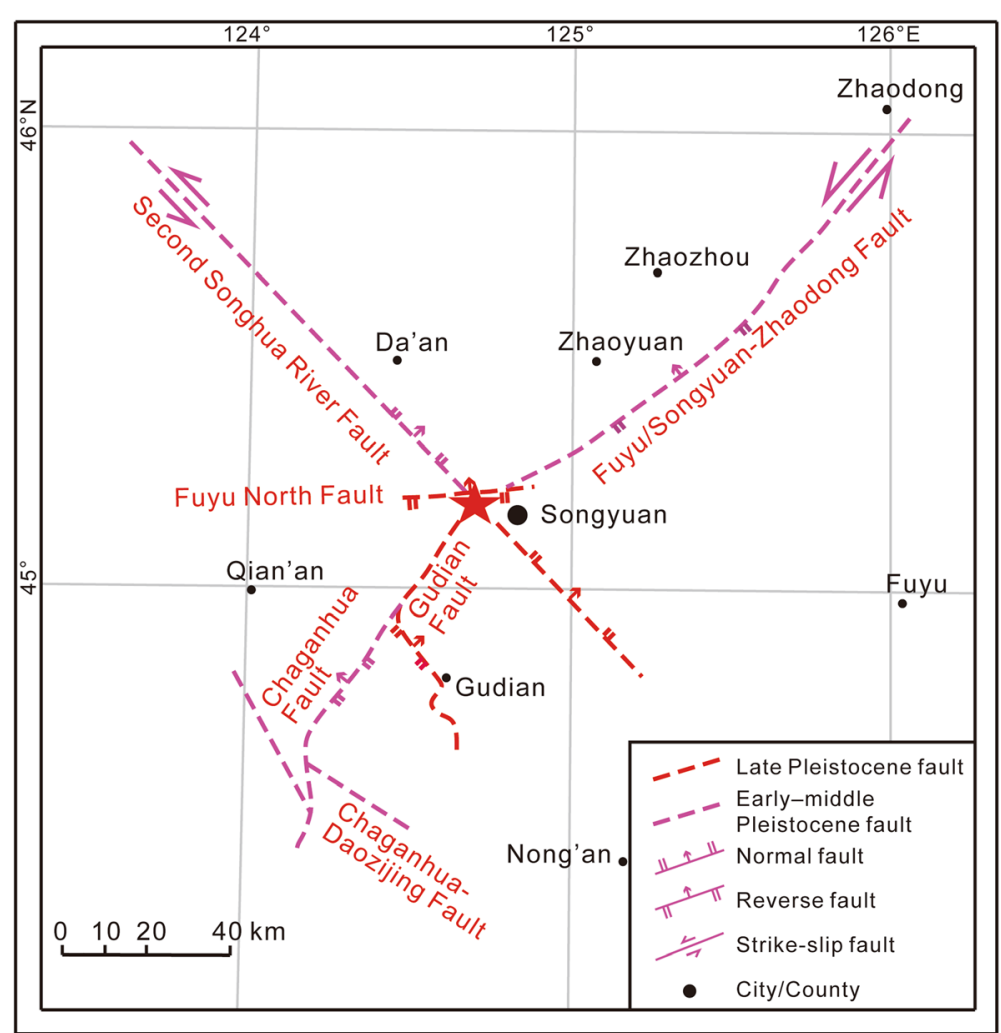

Fig. 2 Faults distribution around Songyuan (modified from Liu et al. 2017b, the red pentagram is the epicenter of the Songyuan M5.7 earthquake)

\subsubsection{Sand volcano with a crater}

During the process of liquefaction and fluidization, overpressure fluid carries the liquefied sand during upwelling process forming channels (cavities) along the fracture zone or stress-reduced zone (Lowe and LoPiccolo 1974; Lowe 1983; Owen 1996; Harris et al. 2000; Owen 2003; Massari et al. 2001; van Loon 2009; Yamaguchi et al. 2012; Phillips et al. 2013; Su et al. 2014), and then pours out of ground surface, which is a sand volcano eruption. The eruption ends as the energy reduces, creating crater-like depressions (Collinson et al. 2006), draw-in structures (Takahama et al. 2000), and sand blows (Obermeier 1996; Tuttle 2001; Owen and Moretti 2011). After fluid pressure is released, the sands deposit as lobes, which are of round shape in plain view and conical or dome-shaped vertically, with varying widths outside and inclined lamination inside (Collinson et al. 2006).

The scale of a sand volcano is directly related to the magnitude and epicentral distance. Generally, the larger the earthquake magnitude is and the smaller the epicentral distance is, the larger scale the sand volcano is. It has been reported that the M5.8 earthquake that occurred in Songyuan in 2013 induced an area of more than $300 \mathrm{~m}^{2}$ of sand volcanoes (Wei et al. 2016).
The maximum diameter of the sand volcano caused by the Songyuan M5.7 earthquake exceeded $12 \mathrm{~m}$ (Fig. 6a). The scale of sand volcanoes decreased as the epicentral distance increased. The minimum diameter of the sand volcano was only $5 \mathrm{~cm}$. The common sand volcano scale was $2-8 \mathrm{~m}$ in diameter, and the crater was usually $0.5-1$ $\mathrm{m}$ in diameter. The thickness of the sand volcanic deposit was large around the crater and gradually decreased outwards, with a variation range of $2-50 \mathrm{~cm}$. The distribution of sand volcanoes can be divided into symmetrical and asymmetric types. Generally, the distribution of sand bodies is symmetrical, widely distributing in a flat surface without obstacles (Fig. 6b); whereas distribution of sand bodies is asymmetric when affected by high topographic fluctuation, surface fractures and obstacles (Fig. 6c, d). In addition, the symmetrical shape of the sand volcano may be affected by the wind direction and other factors. The sand volcanoes were distributed either in isolation (Fig. 6a, d) or in groups (Fig. 6b, c). Volcanoes distributed in groups generally had a dominant orientation, and the dominant distribution direction in Songyuan was N-S, followed by NW-SE (Fig. 5).

Influenced by periodic seismic waves, sand volcanoes also erupt periodically. The sand flows laterally after the eruption to form inclined lamination, as shown in Fig. 7. 


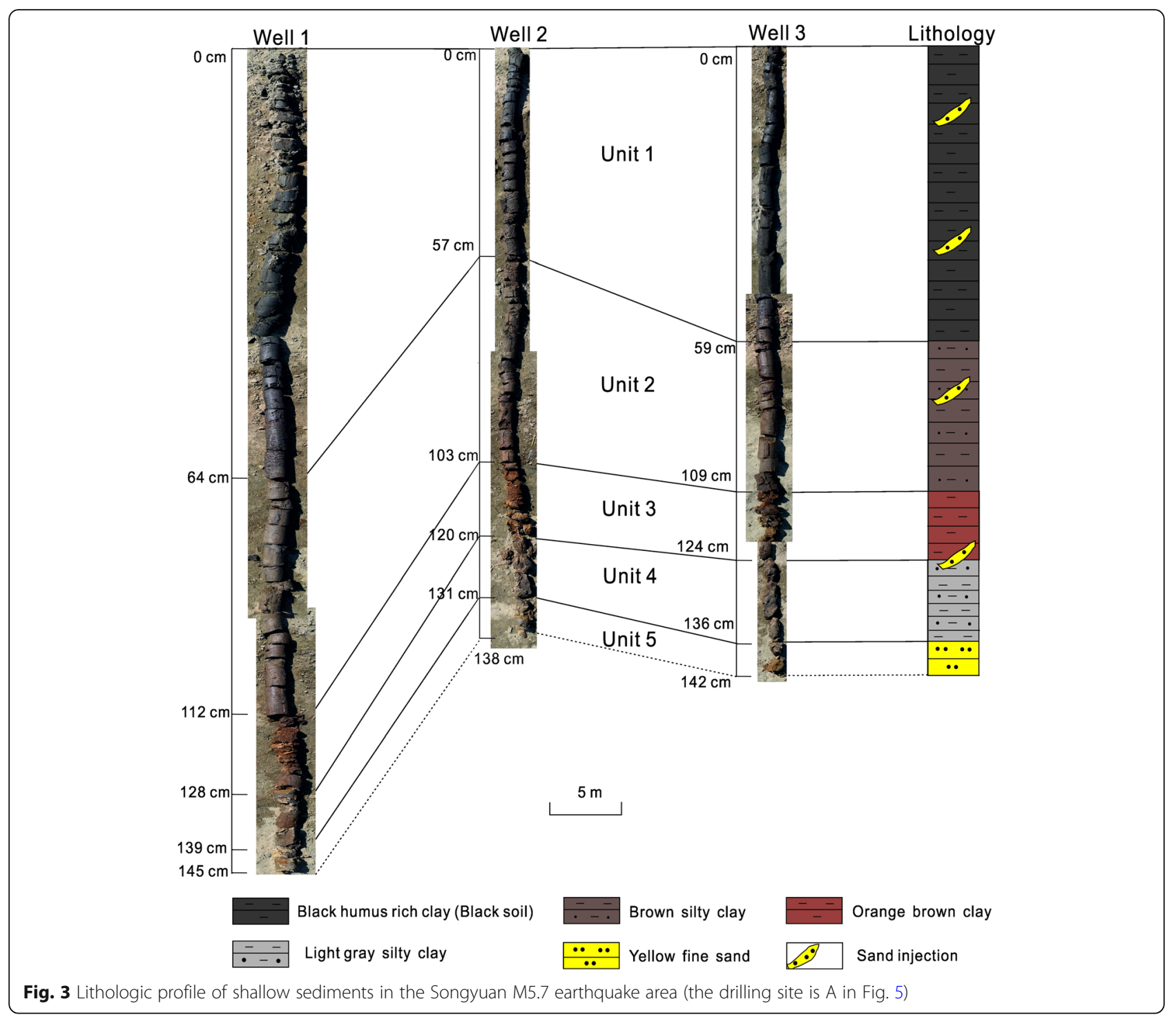

The morphology of inclined lamination is essentially consistent with that of the sand volcanic deposit, which points out from the crater's center to distal end. In the interior, the lamination mostly extends to the interior of the sand volcanic channel due to the refluxing effect of eruption, forming the draw-in structures (Takahama et al. 2000) and gully at the inner edge of the crater (Fig. $6 \mathrm{~b})$. The thickness of inclined laminae within the sand volcanoes varied from (Fig. $8 \mathrm{a}-\mathrm{c}$ ) $0.5 \mathrm{~cm}$ to $5 \mathrm{~cm}$ and normally-graded bedding developed (Figs. 7 and $8 \mathrm{~b}$ ). This represented a single eruption process in which pore-fluid pressure gradually decreased (Rodríguez-Pascua et al. 2015), coarser sediments deposited at the beginning, and then finer sediments deposited as energy reduced. In the vertical profile, sand volcanic sedimentary lenses are often mistaken as beddings, and inclined layering is mistaken for cross-bedding (Collinson et al. 2006).

Upwelling water and sand erode the clay of the surrounding sidewall, forming mud clasts, which erupt and deposit together with sand and water (Obermeier 1996; $\mathrm{Su}$ et al. 2014). These mud clasts are often well-sorted and elliptical, forming imbricate structures after deposition (Fig. 7; Fig. 8d). Mud clasts may not occur in sand volcanoes in a few cases (cf. Li et al. 1996).

\subsubsection{Sand volcano without a crater}

This type of volcanoes is often in the shape of a mound or dune with no craters. They are relatively thicker in the center and wedge out to all sides, and circular or elliptical in the plane and lenticular or conical in vertical direction. Most sand volcanoes without craters are 


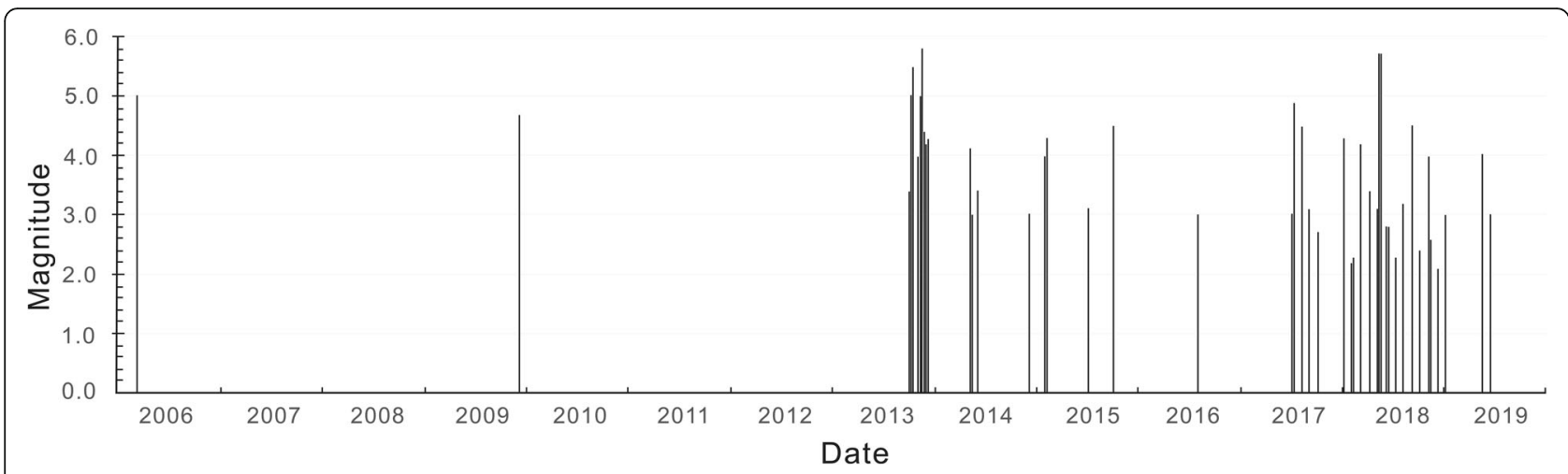

Fig. 4 Earthquake distribution $(M \geq 2)$ in Songyuan area since 2006 (data up to June 3, 2019)

distributed in isolation, while others are linear, $0.2-10 \mathrm{~m}$ in diameter and $0.1-0.6 \mathrm{~m}$ in height. As shown in Fig. $6 \mathrm{~d}$, the elliptical sand volcano without a crater is approximately $0.5 \mathrm{~m}$ high, with the long axis direction close to N-S.

Two conditions are necessary to form sand volcano without a crater. First, there must be sufficient supply of liquefied sand, so that the volcanic vent formed by erupting can be filled in time. Second, the excessive pore-water pressure must be appropriate, which can make the fluid only eject to the ground surface without causing a large crater. Therefore the continuous sandblasting forms sand volcanoes without craters.

\subsubsection{Water volcano (no sand)}

The presence of water volcanoes indicates that there is no sand ejection and deposition during the eruption process. When the earthquake is over, one crater is formed with no sand deposition. As shown in Fig. 9, the water volcano crater is nearly circular with a diameter of $2.2 \mathrm{~m}$ and a settlement of $45 \mathrm{~cm}$. Concentric ring normal faults are developed on the rim of the crater, and it is

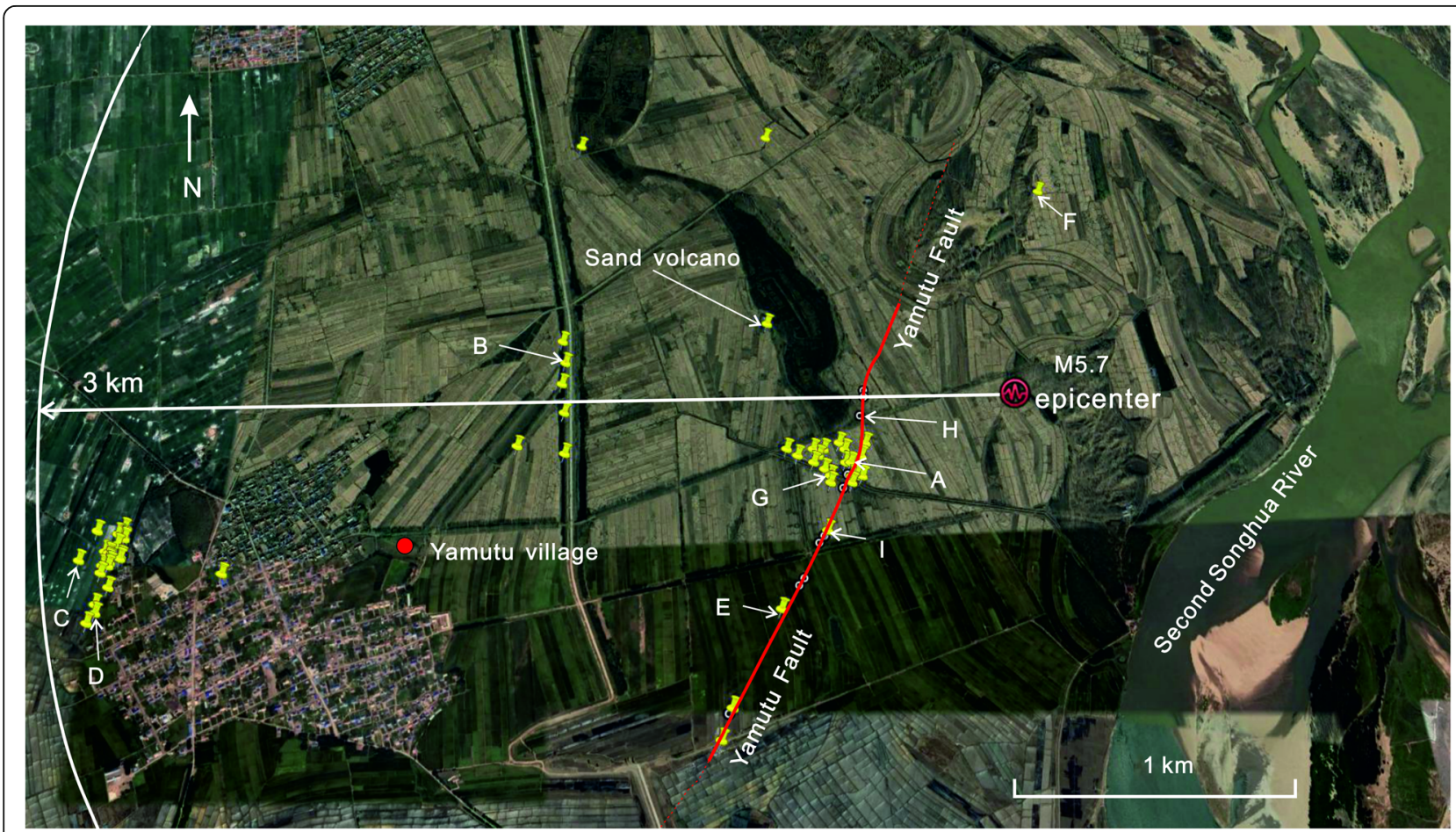

Fig. 5 Distribution of liquefied sand volcanoes induced by the Songyuan M5.7 earthquake (A-I are locations of detailed research and photo collection sites) 

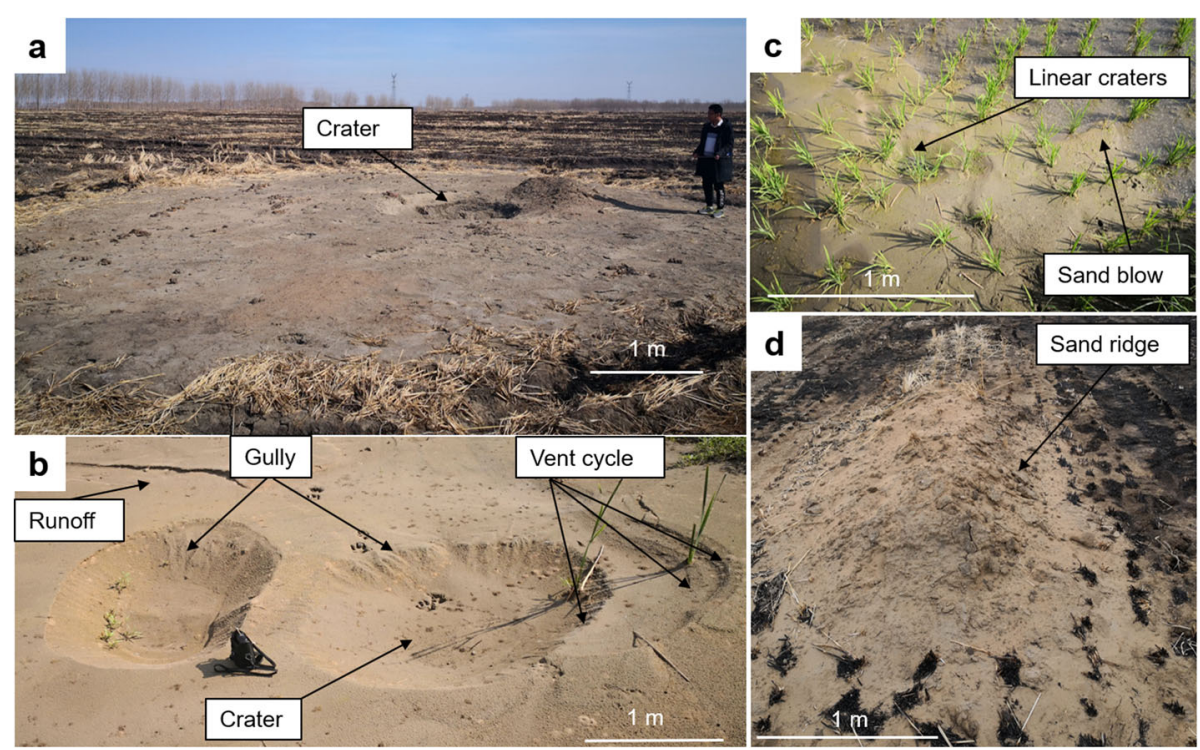

Fig. 6 Morphology and combination features of liquefied sand volcanoes induced by the Songyuan M5.7 earthquake. a An isolated sand volcano, approximately $12 \mathrm{~m}$ in diameter with a crater of approximately $1.3 \mathrm{~m}$ in diameter (photo was taken from site A in Fig. 5); b Sand volcanoes distributed in group with craters of $0.7-1.0 \mathrm{~m}$ in diameter, concentric ring terraces formed by multistage sand volcano eruptions, gully developed in the crater margin and runoff on the surface of sand volcano deposition (photo was taken from site B in Fig. 5); c Small-scale linear sand volcano distributed in groups with a thickness of $2 \mathrm{~cm}$ (photo was taken from site D in Fig. 5); d Hill-shaped isolated sand volcano with no crater, $3.1 \mathrm{~m}$ long, $1.6 \mathrm{~m}$ wide, and $0.45 \mathrm{~m}$ high, with the direction of long axis close to N-S (photo was taken from site E in Fig. 5)

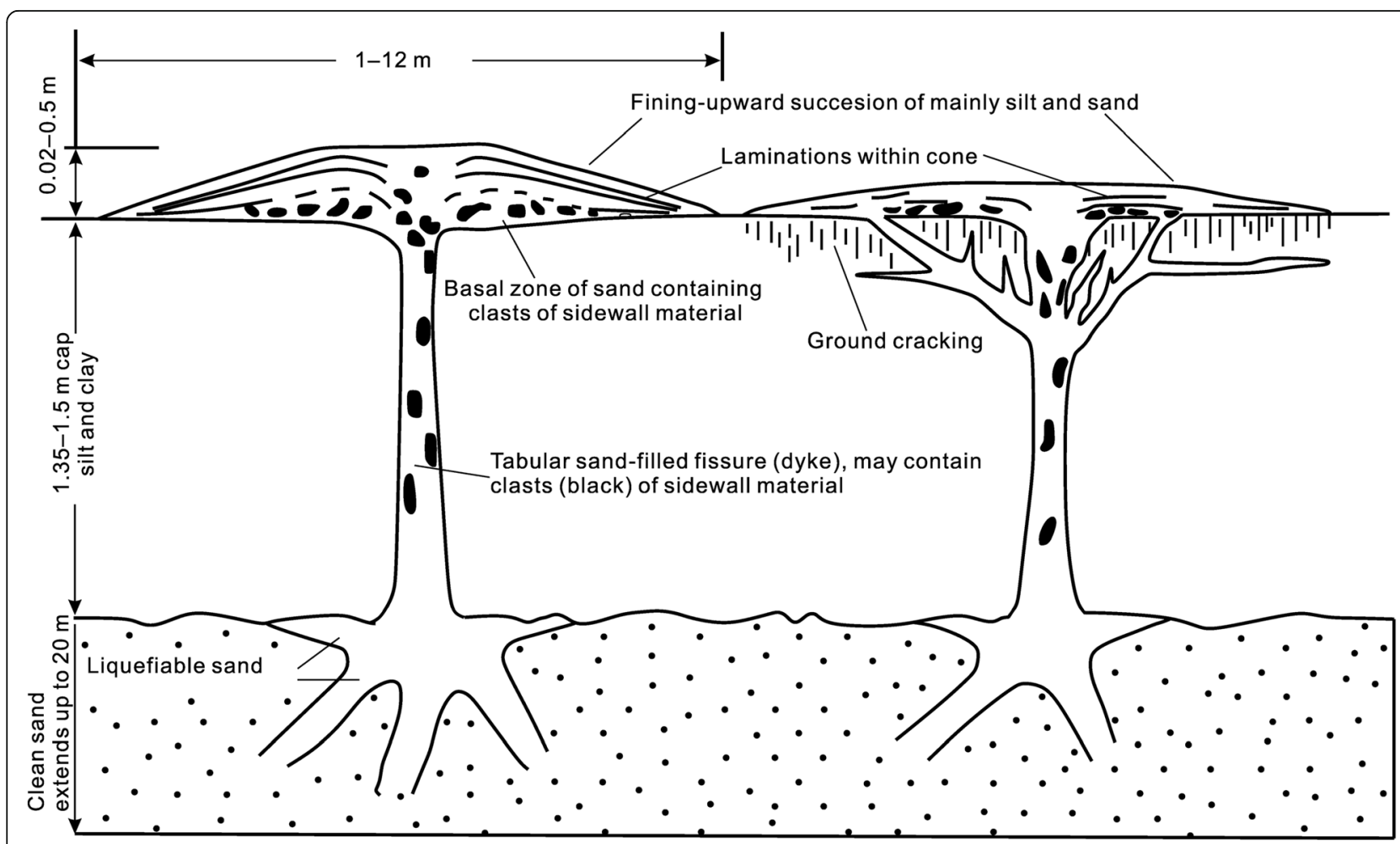

Fig. 7 Sketch of the internal structure of a sand volcano (modified from Obermeier 1996; Su et al. 2014) 


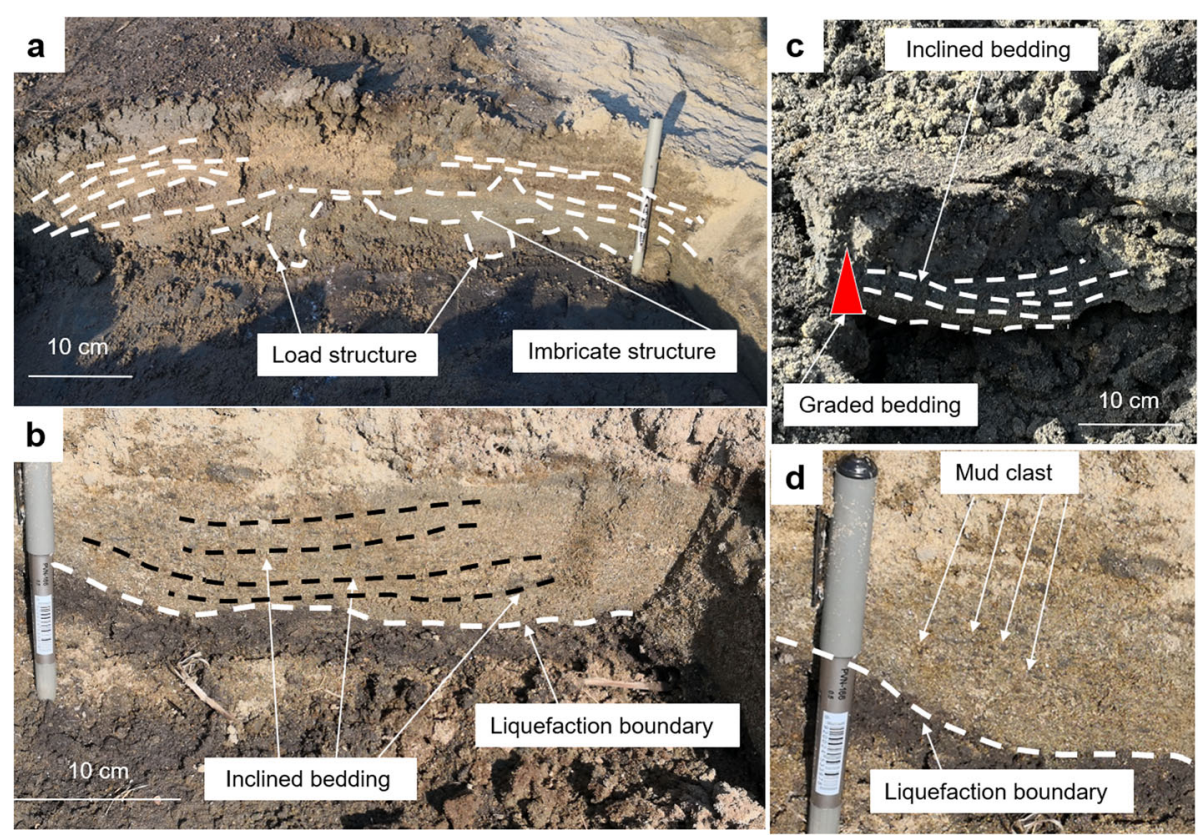

Fig. 8 Internal structure of a sand volcano caused by the Songyuan M5.7 earthquake. a Laterally inclined bedding and load structure of sand volcanic deposits; $\mathbf{b}$ Normal graded bedding and inclined lamination in sand volcanic deposits; c Internal inclined lamination of the sand volcano; d The mud clasts and load structure inside the sand volcano. Photos were taken from the interior of a small exploratory trough (with a depth of approximately $30 \mathrm{~cm}$ ), which located at about $1 \mathrm{~m}$ on the flank of a sand crater (site A in Fig. 5)

inferred that inside the crater, several groups of faults with different directions developed.

Except for one water volcano found in the study area, there were no reports of this type by other researchers. Special geological and hydrodynamic conditions are needed for the formation of this type. First, sands must be inadequate or don't exist in the liquefaction area, as well as in the upwelling fluid. Second, the pore-water pressure should be just appropriate, making it impossible for sand to erupt out of the surface except when carried by water. The dynamic process of this type of volcanic deposition requires further detailed study.

\subsubsection{Model of forming mechanism}

The sand volcanoes induced by earthquakes mainly form in three stages as follows: the preseismic, the coseismic and the postseismic (Fig. 10).

In the preseismic stage, the water-saturated unconsolidated sediments are dominated by well-sorted and rounded fine sands, which are overlain by low-permeable

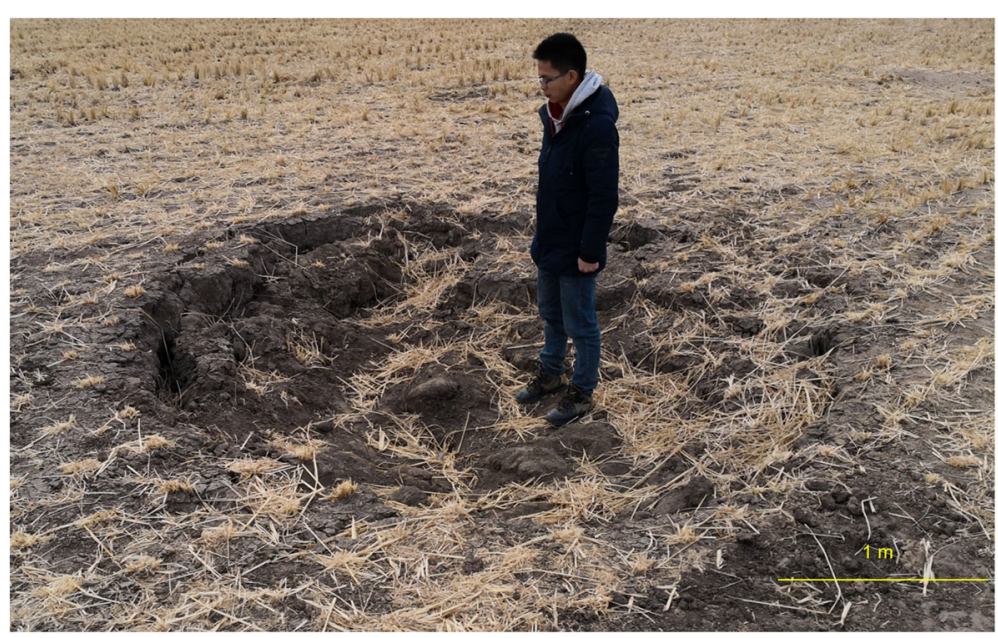

Fig. 9 A water volcano caused by the Songyuan M5.7 earthquake (photo was taken from site C in Fig. 5) 


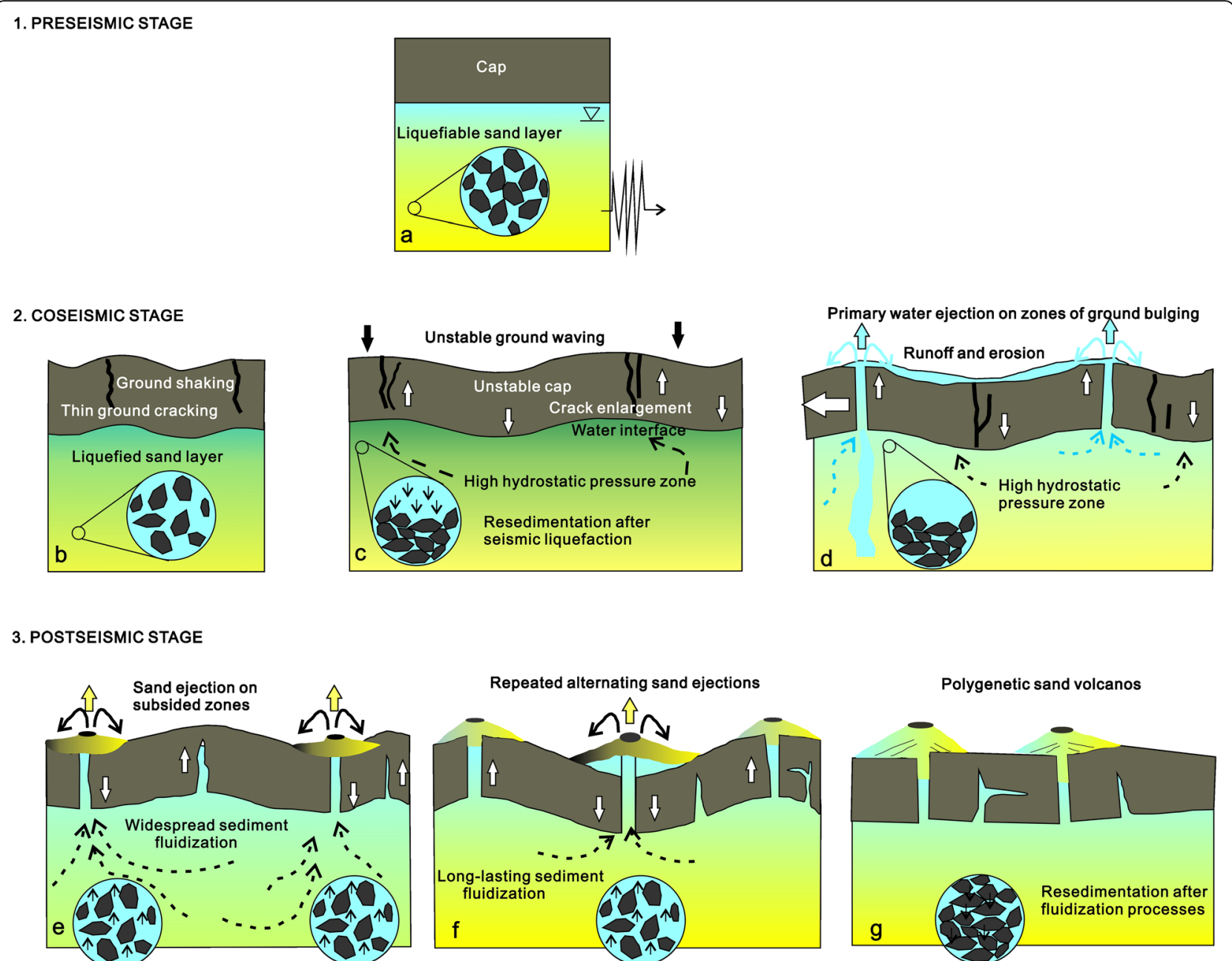

Fig. 10 Sketch of the formation process of a sand volcano induced by an earthquake (modified from Rodríguez-Pascua et al. 2015)

clay and silty clay. The thickness of the overlying layer must be less than a certain value to induce liquefaction (Fig. 10a). During the coseismic stage, the ground shakes under the influence of seismic wave shear force, resulting in cracks. The water moves up because of liquefaction, which gathers at the interface between the clay layer and sand layer (Fig. 10b). The sands redeposit and become tightly packed after one single liquefaction event. The upward buoyancy generated by the gradually increasing excessive pore-water pressure makes the ground surface shake continuously and cracks further expand (Fig. 10c). During the postseismic stage, hydraulic fractures are generated once the excessive pore-water pressure exceeds the hydrostatic pressure, at which point water erupts out and forms a volcano (Fig. 10d). Later, extensive liquefaction and fluidization are caused, making sands vent out with upwelling water through the crater forming a sand volcano (Fig. 10e). More fractures were formed in the process that allows sand and water to continue to erupt and form sand volcanoes (Fig. 10f). When all the seismic energy is released, the excessive pore-water pressure decreases to be less than the hydrostatic pressure, which ends liquefaction and fluidization. As the movement of the surface water and sands stops, the sand volcanism comes to an end (Fig. $10 \mathrm{~g})$.

\subsection{Sand mounds}

The Songyuan M5.7 earthquake induced a wide range of sand mounds (Fig. 11). Sand mounds are formed in two environments: one is on the dune approximately $2 \mathrm{~m}$ above the ground surface, which is dominated by fine sand and silt (Fig. 11a). The other occurs on sand volcanoes, which can form in both the crater interior and the lateral lobes (Fig. 11b, c). The shape of the sand mounds is similar to that of a volcanic cone, with or without a crater. They are round in plain view and lens-like in vertical profile, $3-15 \mathrm{~cm}$ in diameter and $3-8 \mathrm{~cm}$ in height. Sand mounds are most commonly developed in groups, 


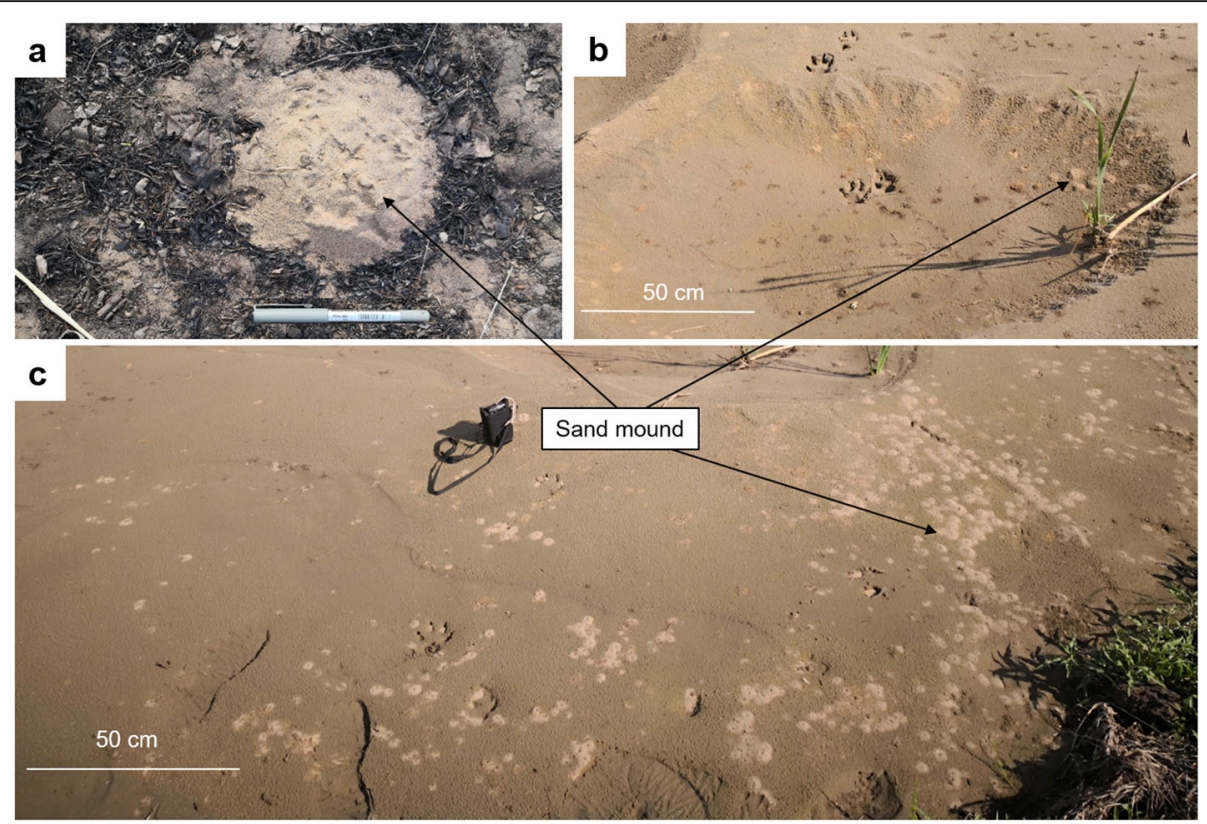

Fig. 11 Sand mounds induced by the Songyuan M5.7 earthquake. a An isolated sand mound, $13 \mathrm{~cm}$ in diameter (photo was taken from site C in Fig. 5); $\mathbf{b}$ An isolated sand mound inside a sand crater, $4-7 \mathrm{~cm}$ in diameter (photo was taken from site B in Fig. 5); c Groups of sand mounds on the flanking surface of a sand volcano, $3-5 \mathrm{~cm}$ in diameter (photo was taken from site B in Fig. 5)

and the sand piles are relatively coarse grained and gradually transfer to finer sands towards the cone top. Small inclined lamination can be found inside the sand mounds, with the tilting angle of approximately $30^{\circ}$.

Sand mound is a special type of sand volcano ( $\mathrm{Su}$ et al. 2014), which is also induced by earthquake liquefaction. However special conditions are required for forming this type of structure. First, sand mounds are formed by sand layers rather than low-permeable clay, and the sands within the layers are well-sorted and rounded, which are easy to liquefy. Second, the excessive pore-water pressure must be appropriate, as a too small pressure cannot induce eruption while a too large one leads to large sand volcanoes formation. Otherwise, the sand layer is in undersaturation condition when sand mounds form, which means sands are unable to flow or just able to be transported for a short distance after ejection. Sands accumulated due to the weight near the crater with coarser sands distributing at proximal end, which is different from the deposition feature of conventional sand volcanoes.

Due to liquefaction, the water and sand moving up to the clay surface continue upward migration and vent out of the sand dune surface to form the first type (Fig. 11a). The water and sand continuously erupt to the surface to from the second type of sand mound when excessive pore-water pressure inside the sand volcano is just appropriate. This type of sand mound is of small scale and without a crater due to the reduced energy (Fig. 11b, c).

\subsection{Sand dike and sand sill}

The scale of the sand dike and sand sill is controlled by the magnitude and epicenter distance. The width of the sand dike caused by the Songyuan M5.7 earthquake is $3-11 \mathrm{~cm}$, and the lateral extension length is $0.2-2 \mathrm{~m}$. The thickness of the sand sill is $5-15 \mathrm{~cm}$, and the lateral extension is more than $50 \mathrm{~m}$ (Fig. 12). Generally, a large thickness of the liquefied sand layer, a moderate thickness of the overlying low-permeable seal and a high groundwater level favor the formation of sand dikes and sills. Sand dikes and sills are two of the most important structures caused by earthquakes (Obermeier and Pond 1999; Obermeier and Dickenson 2000; Rodríguez-Pascua et al. 2000; Tuttle 2001; Shi et al. 2007; van Loon 2009; Berra and Felletti 2011; Topal and Özkul 2014; HilbertWolf et al. 2016; Ko et al. 2017; Brogi et al. 2018; Zhong et al. 2018).

There are three mechanisms for the formation of sand dikes and sand sills: hydraulic fracturing, lateral spreading and surface oscillation (Obermeier and Pond 1999). As liquefaction intensifies, the sand dikes and sand sill evolve into a large sand intrusive complex that can be tens of meters thick, extending up to thousands of square kilometers (Satur and Hurst 2007; Zhong et al. 2018; Grippa et al. 2019).

In addition to forming sand volcanoes, the liquefied sand invades the overlying cap layer, which tends to develop along the volcanic channel and the interface between the sand and clay, as well as the interface of 

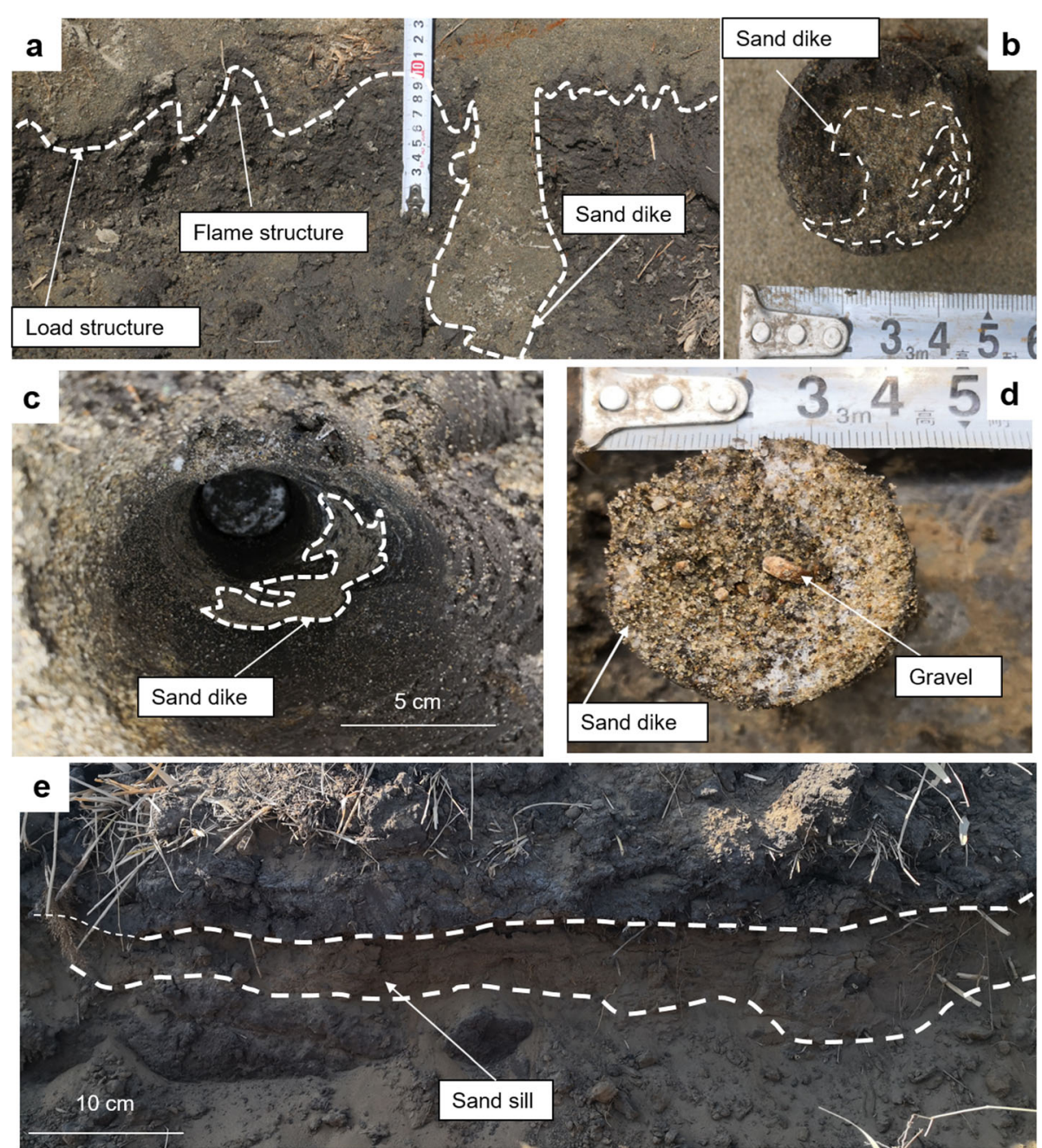

Fig. 12 Liquefied sand dike and sand sill induced by the Songyuan M5.7 earthquake. a Columnar liquefied sand dike, $3-7 \mathrm{~cm}$ wide, $10 \mathrm{~cm}$ high, filling a vertical surface fracture (photo was taken from site A in Fig. 5); b Liquefied sand dike in a shallow drilling core with a burial depth of 45 cm (photo was taken from site A in Fig. 5); c Liquefied sand dike, cloud-like (photo was taken from site A in Fig. 5); d Liquefied coarse-grained sand dike with gravel at a burial depth of $1.1 \mathrm{~m}$ (photo was taken from site B in Fig. 5); e Sand sill, 7-15 cm thick, $55 \mathrm{~cm}$ deep from the surface (photo was taken from site G in Fig. 5)

various lithologies within the clay layer (Fig. 3). The direction and shape of sand dikes can be various, cloudlike, floating band, mushroom-like, columnar, etc. Sand sills are one kind of sand dikes that develop horizontally or parallel to the bedding and are generally larger than the normal size of sand dikes.

\subsection{Other liquefaction-associated structures}

There are some other soft-sediment deformation structures induced by earthquake liquefaction, such as load structure (Alfaro et al. 1997, 2010; Owen et al. 2011; Tian et al. 2014; Topal and Özkul 2014), flame structure (Pisarska-Jamroży et al. 2019), sand pillar (Lowe and LoPiccolo 1974; Mount 1993; Moretti et al. 1999; Valente et al. 2014; Oppo and Capozzi 2016), slump fold (Alsop and Marco 2011; Martín-Chivelet et al. 2011; Ko et al.
2017), convolute bedding (Allen 1977; Obermeier 1996; Alfaro et al. 2010; Kundu et al. 2011), dish structure (Owen 1987; Alfaro et al. 2006), water-escape structure (Lowe 1975, 1976; Owen 1996; Moretti et al. 1999; Gibert et al. 2011) and so on. The soft-sediment deformation structures found in this study include load structure, flame structure and deformation bedding (Fig. 8a, c, d; Fig. 12a).

\section{Vertical succession across the liquefied zone}

Vertically, the liquefaction structure formed in Songyuan M5.7 earthquake distributes in four obvious zones from bottom to top (Fig. 13): (1) Thoroughly liquefied zone. Fine unconsolidated sand with a large thickness is easily liquefied under the influence of seismic shear stress. The groundwater table is also located in this zone, generally at a depth of $2-5 \mathrm{~m}$. One criterion for the formation of 


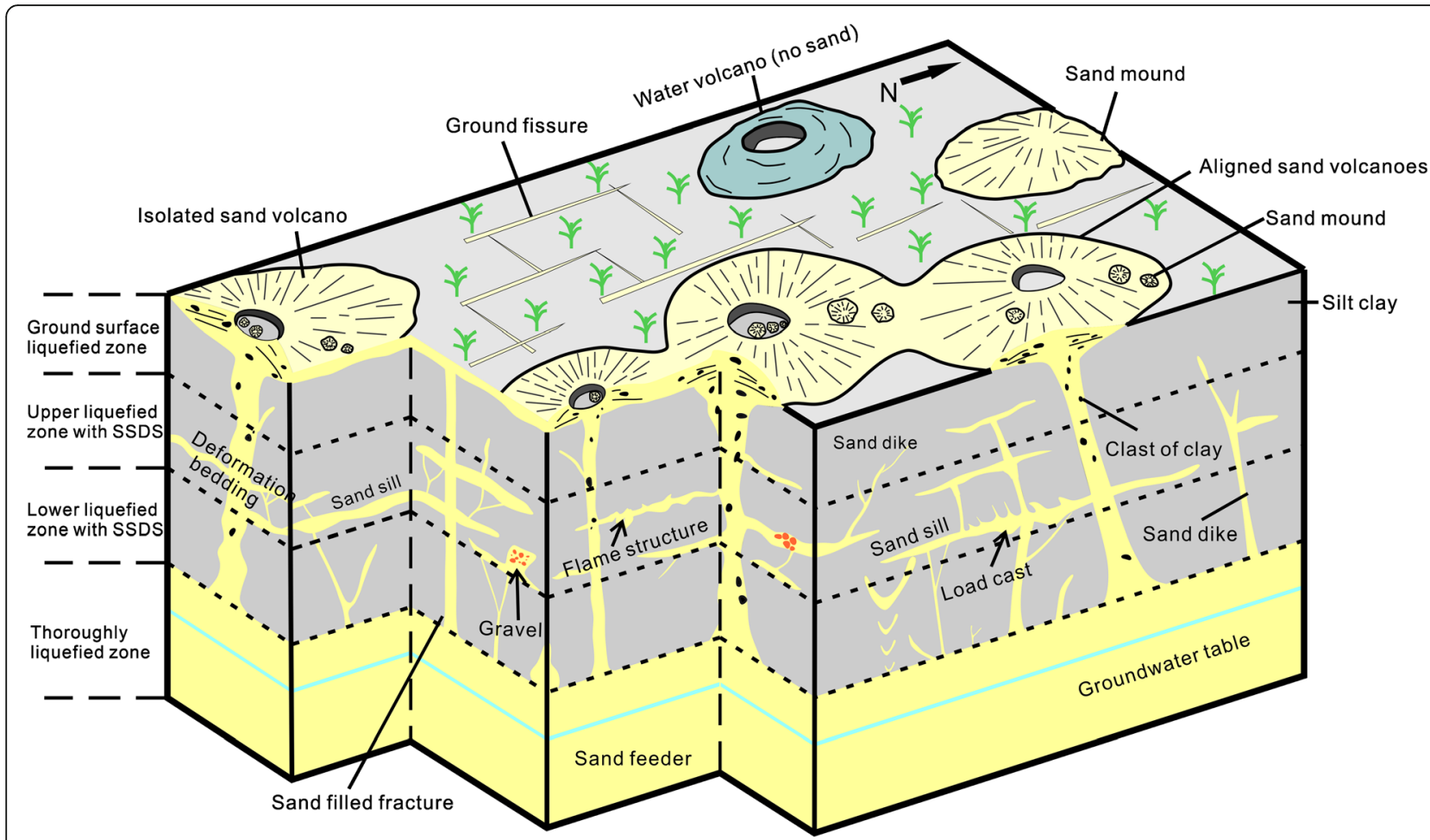

Fig. 13 Sketch of the vertical liquefaction structures distribution zones and 3D liquefaction model for the Songyuan M5.7 earthquake (modified from Collinson et al. 2006)

liquefaction is that the unconsolidated sand is watersaturated. Thus, the groundwater table should not be too low; otherwise, no liquefaction will occur. Deformation bedding, convolute bedding and water-escape structure can also be found in this zone. (2) Lower liquefied zone with SSDS. It is located at the lower part of the overlying low-permeable clay, closer to the sand layer. Affected by liquefaction and fluidization, high pore-pressure fluid and sand mixture upwells through the lithologic boundary and invade into the overlying clay to form sand dikes, sand sills, associated deformation beddings and load structures. (3) Upper liquefied zone with SSDS. It is located near the surface. Influenced by fractures, lithologic interfaces and beddings, the upwelling water with sand and clay particles intrudes into the clay layer to form sand dikes and sand sills, as well as associated deformation beddings and load structures. (4) Ground surface liquefied zone. The main liquefaction structures are sand volcanoes, sand mounds, sand dikes, load structures, and so on. Based on the regional geological characteristics, the 3D liquefaction model of Songyuan M5.7 earthquake is summarized in Fig. 13.

\section{Discussion}

Songyuan area has been seismically active since 2006, especially in 2013, and an M5.8 earthquake cluster occurred in the Qianguo area, indicating an active tectonic movement. Some researchers proposed that the activity of the NE-SW trending and NW-SE trending faults was the focal mechanism (Chen et al. 2015; Li and Wang 2018). However, different specific faults were determined as the seismogenic faults (Fig. 1b), such as the TongyuChangchun Fault (Xue et al. 2015), the Second Songhua River Fault (Yang et al. 2010), the Gudian Fault (Shao et al. 2015), the Fuyu/Songyuan-Zhaodong Fault (Wang et al. 2015a; Liu et al. 2017b), and the ChaganhuaDaozijing Fault (Pan et al. 2018). It was also reported that the earthquakes can be caused by the exploration and production activities of oil companies (Liu et al. 2017a). Therefore, many controversies have made it difficult to draw a conclusion.

A normal ground fault, the Yamutu Fault in this paper developed near the epicenter after the Songyuan M5.7 earthquake (Fig. 5). As shown in Fig. 14, the fault struck $\mathrm{NE} 35^{\circ}, 1.5-2.8 \mathrm{~m}$ in width, with a fault distance of 10 $30 \mathrm{~cm}$. The Yamutu Fault is characterized by a typical double-fault graben structure, which reflects the release of seismic stress to the surface. Tensile fissures developed widely around the earthquake zone, and the scale and distribution density of fissures were larger surrounding the Yamutu Fault compared to other areas neighbouring the earthquake zone (Fig. 15). The fissures can be divided into two types. One type was conjugate joints, which occur in pairs, acting as tracking tension joints, 

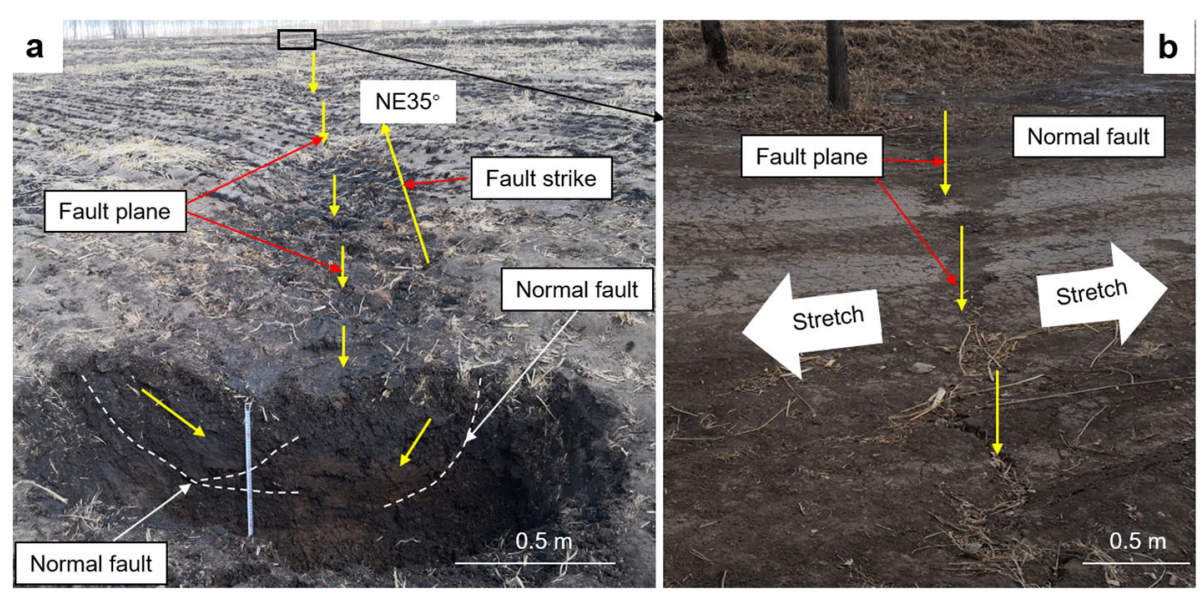

Fig. 14 Yamutu Fault formed after the Songyuan M5.7 earthquake. a Double-fault graben structure in Yamutu Fault (photo was taken from site A in Fig. 5); b Local feature of Yamutu Fault (magnification of the rectangle in a), cutting off the road (photo was taken from site $\mathrm{H}$ in Fig. 5)

and the joint trends of the two groups were $0^{\circ}-180^{\circ}$ and $80^{\circ}-260^{\circ}$ (Fig. 15a, a'). The other type of tensile fissure was $0^{\circ}-180^{\circ}$ dominant in the direction, with a stable distribution of approximately $1 \mathrm{~m}, 0-4 \mathrm{~cm}$ in width, extending over $50 \mathrm{~m}$. Except for a few, most of the fissures were not filled with sand (Fig. 15b). Based on the regional geological setting, ground fault type and extension direction, and the conjugate joints after the earthquake, it is preliminarily judged that the regional stress field for the M5.7 earthquake in Songyuan on May 28, 2018 is

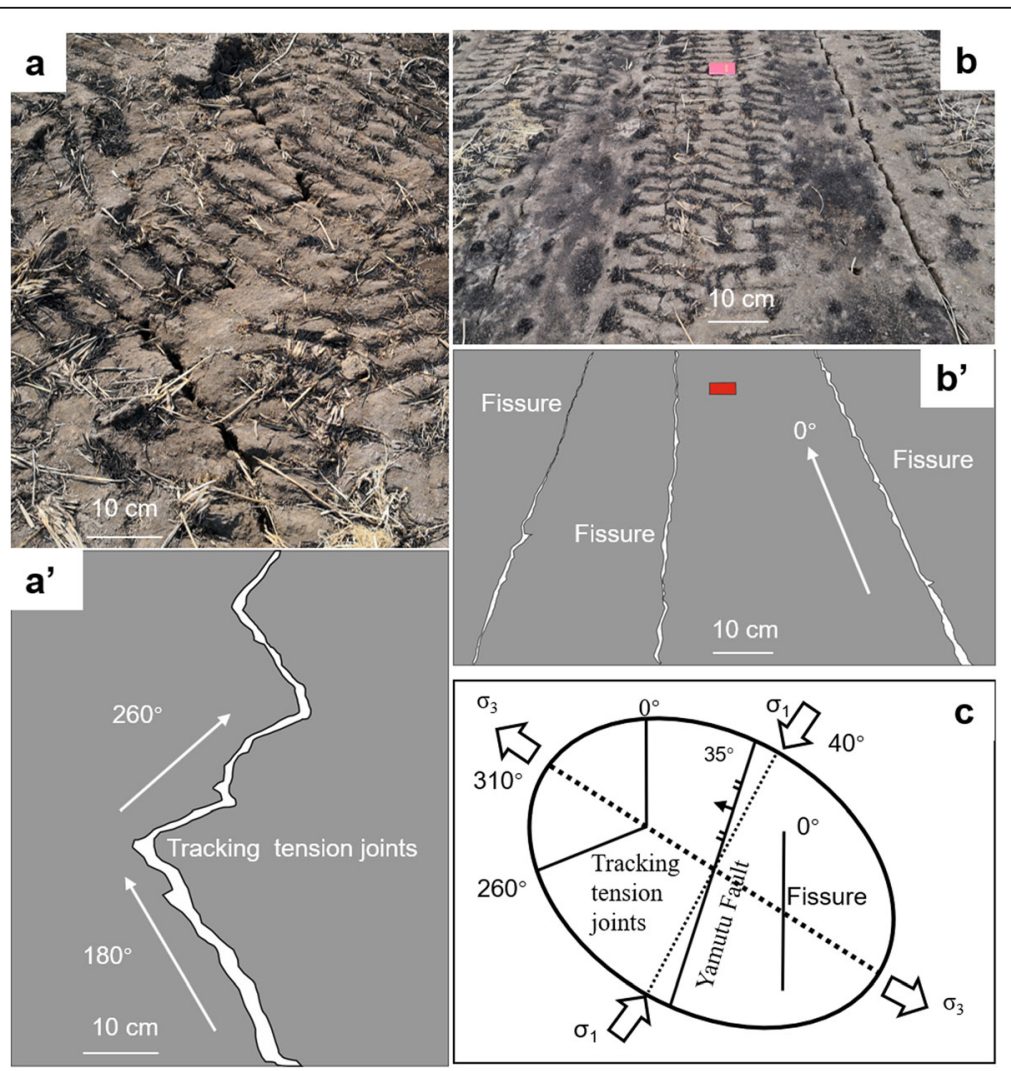

Fig. 15 Ground fissure and stress field pattern of the Songyuan M5.7 earthquake. a Tracking tension joints; the extension directions are $0^{\circ}-180^{\circ}$ and $80^{\circ}-260^{\circ}$, respectively (photo was taken from site I in Fig. 5); $\mathbf{a}^{\prime}$ Sketch of $\mathbf{a}$; $\mathbf{b}$ Ground fissures with extension directions of $0^{\circ}-180^{\circ}$ (photo was taken from site I in Fig. 5); b' Sketch of $\mathbf{b}$; c Model diagram of the stress field in the Songyuan M5.7 earthquake area 
characterized by its maximum compressive stress with a main direction of $40^{\circ}-220^{\circ}$, and its minimum tensile stress with a main direction of $130^{\circ}-310^{\circ}$ (Fig. 15c). The extension direction of the Yamutu Fault is essentially the same as that of the Fuyu/Songyuan-Zhaodong Fault (Fig. 1b). It is speculated that the Fuyu/Songyuan-Zhaodong Fault is a seismogenic fault, however further research is needed to verify this viewpoint.

The Second Songhua River in the Songnen Plain flows through Songyuan, which is less than $500 \mathrm{~m}$ from the epicenter of the M5.7 earthquake. The average water level of the river is $129.32-134.95 \mathrm{~m}$ (Tian et al. 2014). The altitude around Yamutu village is $128-137 \mathrm{~m}$. The ground ice in this area melts late, and the burial depth of the groundwater table in the earthquake zone is relatively shallow, which is estimated to be $2-5 \mathrm{~m}$ deep. The cyclic shear force generated by seismic activities is greater than the initial liquefaction shear force at this depth (see Obermeier 1996: Fig. 3). Another important condition for an earthquake-induced liquefied sand volcano is that the impermeable layer should not be too thick. Sufficient sand thickness is a prerequisite for liquefaction. A thick seal layer increases the load pressure and shear strength so that liquefaction cannot occur. The thickness of the sealing layer is usually $1-5 \mathrm{~m}$, and may be up to $16 \mathrm{~m}$ (Obermeier and Pond 1999). The thickness of clean unconsolidated sands under the clay layer in the Songyuan area exceeds $20 \mathrm{~m}$ (Fig. 3: Unit 5). According to the China earthquake intensity scale (1980) (Lu 1981), M5.7 of Songyuan earthquake was VII. According to the research method of Ishihara (1985) (Obermeier and Dickenson 2000), the surface acceleration of the Songyuan earthquake was $0.17 g$ ( $g$ is the gravity acceleration), and it was concluded that the thickness of the liquefied sand zone of the Songyuan M5.7 earthquake was approximately $2 \mathrm{~m}$.

The range of surface liquefaction is controlled by the magnitude and focal depth. According to different formulas or charts of the correlation between the maximum liquefaction epicenter distance and magnitude proposed by different researchers, the maximum liquefaction radius of the Songyuan M5.7 earthquake was $2.878 \mathrm{~km}$ (Kuribayashi and Tatsuoka 1975), 2-10 km (Obermeier and Pond 1999), and 4-13 km (Tuttle 2001; Bonini 2009), respectively. In this study, through field investigation and calculation, we found that the maximum liquefaction radius of the Songyuan M5.7 earthquake was $3 \mathrm{~km}$.

\section{Research significance}

The liquefaction structures induced by the Songyuan M5.7 earthquake provide a good example for studying modern earthquakes. Liquefaction-related deformation structures can occur in a variety of sedimentary environments and can be triggered by a variety of factors (Moretti et al. 2016; Shanmugam 2016), of which the identification of earthquake genesis is a topic of research interest yet remains challenging. Our study provides three-dimensional spatial parameters for the analysis of palaeoearthquakes and liquefaction structures (Tuttle 2001), which makes up for the shortcomings of experimental simulation (Nichols et al. 1994; Owen 1996; Moretti et al. 1999; Ross et al. 2011; Tian et al. 2014). Liquefaction structures are also important in restoring earthquake magnitude.

Songyuan is located in a seismically active zone, and frequent earthquakes have brought serious disasters to local agriculture and hydrocarbon exploration and production activities. Research on earthquake liquefaction structures can predict disaster-prone areas and influencing areas and thus can guide local industrial and agricultural production, construction and oil field exploration and production dynamic monitoring.

Songyuan is located at the hinterland of the Songliao Basin. Frequent earthquakes reveal active tectonic movements in the surrounding areas. This study is helpful in determining the rules of regional tectonic stress field and fault activity, and providing basic data for basin evolution and plate activity research.

\section{Conclusions}

1) The Songyuan M5.7 earthquake resulted in various liquefaction structures. The most common type is sand volcano, including sand volcano with a crater, sand volcano without a crater, water volcano (no sand), sand mounds, sand dikes and sand sills. Some liquefaction-related structures, such as load structure, flame structure, deformation bedding, slump fold, sandstone pillar, convolute bedding, dish structure and water-escape structure, are also induced by earthquakes but occur relatively infrequently.

2) The formation of liquefied sand volcanoes includes three stages respectively as excessive pore-water pressure building up in the liquefied sand layer, rupture of the overlying low-permeable layer, and eruption of water and sand. The vertical distribution of liquefaction structures can be divided into four zones from bottom to top, i.e., the thoroughly liquefied zone, the lower liquefied zone with SSDS, the upper liquefied zone with SSDS, and the ground surface liquefied zone. The distribution of liquefied sand volcanoes is zonal, mainly extending in the direction of N-S, followed by NW-SE. The underground liquefaction structures are mainly sand dikes, sand sills and others.

3) In addition, 2-5-m-deep groundwater table, 1.351.5 -m-thick low-permeable clay, and more than 20$\mathrm{m}$-thick unconsolidated clean fine sand are favorable conditions for the formation of extensive 
liquefaction structures induced by the Songyuan M5.7 earthquake. The liquefied sand was more than $2 \mathrm{~m}$ thick, and liquefied sand volcanoes can be seen within the range of epicenter distance of $3 \mathrm{~km}$ on the surface.

4) One NE35 trench-type normal fault developed on the ground surface after the Songyuan M5.7 earthquake, accompanied by a widely distributed $0^{\circ}-180^{\circ}$ extensional fracture and two groups of tracking tensile fractures $\left(0^{\circ}-180^{\circ}\right.$ and $\left.80^{\circ}-260^{\circ}\right)$. The direction of the maximum main compressive stress in the Songyuan area was $40^{\circ}-220^{\circ}$, and the direction of the minimum main tensile stress is $130^{\circ}-310^{\circ}$. The Fuyu/Songyuan-Zhaodong Fault is likely to be a seismogenic fault.

5) Research on the Songyuan earthquake-induced liquefaction structures provides three-dimensional spatial parameters for study on palaeoearthquakes and liquefaction structures, provides directions for prediction of modern earthquake and disasterprone areas, and provides a foundation for regional structural research.

\section{Abbreviations}

SSDS: Soft-sediment deformation structures

\begin{abstract}
Acknowledgements
Many thanks to Yang Wang, Wei Chen and Dong-Hao Peng from Jilin Oilfield for their help in the field investigation. We thank Dr. Lv Wang from Monash University and Dr. Gail Maxwell from the University of Aberdeen for their valuable advice on sedimentology, and we also thank Dr. Gui-Dong Ping and Dr. Zhao-Han Xie for the discussion we had about the regional tectonic stress field. We are grateful to Professor Zeng-Zhao Feng, editors and two anonymous reviewers for their editorial work and many constructive comments and suggestions that greatly improved this manuscript.
\end{abstract}

\begin{abstract}
Authors' contributions
ZFS applied for the funding, performed the research, analyzed the data, compiled a few figures and wrote the manuscript. JHZ designed the work, took part in the field trip and interpreted the data. $\mathrm{JH}$ interpreted part of the data and revised the manuscript. $\mathrm{BH}$ took part in the field trip, collected data and compiled Fig. 5. XWL interpreted part of the data and revised the manuscript. ZXL collected papers and completed some figures. WMR collected some data and compiled Fig. 2. YFZ, HQY, and JLL interpreted some of the data. LTN and GXS took part in fieldwork and collected data. $J J$, WXZ and BZ interpreted some data and compiled some figures. All authors approved the final manuscript.
\end{abstract}

\section{Funding}

This study is supported by the "Natural Science Foundation of Heilongjiang Province (No. JJ2016ZR0573)", "Youth Foundation of Northeast Petroleum University (No. NEPUBS201503)", "Northeast Petroleum University Scientific Research Start-up Fund", "Shandong Provincial Key Laboratory of Depositional Mineralization and Mineral Foundation (No. DMSMZO17009)", and "Natural Science Foundation of Shandong Province (No. ZR2016DB15)".

\section{Availability of data and materials}

All data generated or analyzed during this study are included in this published article. Additional data related to this paper can be requested from the corresponding author.

\section{Competing interests}

The authors declare that they have no competing interests.

\section{Author details}

'School of Geosciences, Northeast Petroleum University, Daqing 163318, Heilongjiang Province, China. ${ }^{2}$ Shandong Provincial Key Laboratory of Depositional Mineralization and Sedimentary Mineral, Shandong University of Science and Technology, Qingdao 266590, Shandong Province, China. ${ }^{3}$ Department of Geology and Petroleum Geolog, University of Aberdeen, Aberdeen AB24 3UE, UK. ${ }^{4}$ School of Geosciences, China University of Petroleum, Qingdao 266580, Shandong Province, China. ${ }^{5}$ Qingdao Institute of Marine Geology, China Geological Survey, Qingdao 266071, Shandong Province, China.

Received: 12 August 2019 Accepted: 29 December 2019

Published online: 04 February 2020

\section{References}

Alfaro, P., J. Galindo-Zaldívar, A. Jabaloy, Á.C. López-Garrido, and C. Sanz de Galdeano. 2006. Estructuras sedimentarias de deformación interpretadas Como sismitas en el Mioceno superior (Turoliense) de la Cuenca de Granada (cordillera Bética). Geogaceta 40: 255-258.

Alfaro, P., L. Gibert, M. Moretti, F.J. García-Tortosa, C. Sanz de Galdeano, J. Galindo-Zaldívar, and Á.C. López-Garrido. 2010. The significance of giant seismites in the Plio-Pleistocene Baza palaeo-lake (S Spain). Terra Nova 22 (3): 172-179.

Alfaro, P., M. Moretti, and J.M. Soria. 1997. Soft-sediment deformation structures induced by earthquakes (seismites) in Pliocene lacustrine deposits (Guadix-Baza Basin, central Betic cordillera). Eclogae Geologicae Helvetiae 90: 531-540.

Allen, J.R.L. 1977. The possible mechanics of convolute lamination in graded sand beds. Journal of the Geological Society 134 (1): 19-31.

Allen, J.R.L. 1982. Sedimentary structures: Their character and physical basis, 1663. Amsterdam: Elsevier.

Allen, J.R.L. 1986. Earthquake magnitude-frequency, epicentral distance, and soft-sediment deformation in sedimentary basins. Sedimentary Geology 46 (1-2): 67-75.

Allen, J.R.L., and N.L. Banks. 1972. An interpretation and analysis of recumbent-folded deformed cross-bedding. Sedimentology 19 (3-4): 257-283.

Alsop, G.l., and S. Marco. 2011. Soft-sediment deformation within seismogenic slumps of the Dead Sea Basin. Journal of Structural Geology 33 (4): 433-457.

Berra, F., and F. Felletti. 2011. Syndepositional tectonics recorded by softsediment deformation and liquefaction structures (continental Lower Permian sediments, southern Alps, northern Italy): Stratigraphic significance. Sedimentary Geology 235 (3-4SI): 249-263.

Bhattacharya, S., M. Hyodo, K. Goda, T. Tazoh, and C.A. Taylor. 2011. Liquefaction of soil in the Tokyo Bay area from the 2011 Tohoku (Japan) earthquake. Soil Dynamics and Earthquake Engineering 31 (11): 16181628.

Bonini, M. 2009. Mud volcano eruptions and earthquakes in the northern Apennines and Sicily, Italy. Tectonophysics 474 (3): 723-735.

Brogi, A., E. Capezzuoli, M. Moretti, E. Olvera-García, P.F. Matera, V. GardunoMonroy, and A. Mancini. 2018. Earthquake-triggered soft-sediment deformation structures (seismites) in travertine deposits. Tectonophysics 745: 349-365.

Burne, R.V. 1970. The origin and significance of sand volcanoes in the Bude formation (Cornwall). Sedimentology 15 (3-4): 211-228.

Capaccioni, B., M. Coltorti, M. Todesco, S. Cremonini, D. Di Giuseppe, B. Faccini, and U. Tessari. 2017. Sand volcano generated by a violent degassing from methane-saturated aquifers: The case study of Medolla (Modena, Italy). Engineering Geology 221: 91-103.

Chen, J., and H.S. Lee. 2013. Soft-sediment deformation structures in Cambrian siliciclastic and carbonate storm deposits (Shandong Province, China): Differential liquefaction and fluidization triggered by storm-wave loading. Sedimentary Geology 288: 81-94.

Chen, J.T., A.J. van Loon, Z.Z. Han, and S.K. Chough. 2009. Funnel-shaped, breccia-filled clastic dykes in the late Cambrian Chaomidian formation (Shandong Province, China). Sedimentary Geology 221: 1-6. 
Chen, Z.Q., C.Z. Wu, S.J. Zhang, Y.M. Xiao, and D. Wang. 2015. Sequence analysis of strong earthquake group in the M5.8 in 2013. Journal of Disaster Prevention and Reduction 31 (3): 11-15 (in Chinese with English abstract).

Collinson, J.D., N. Mountney, and D.B. Thompson. 2006. Sedimentary Structures (3rd edition), 1-292. Harpenden: Terra.

Du, Y.S., and W.C. Yu. 2017. Earthquake-caused and non-earthquake-caused soft-sediment deformations. Journal of Palaeogeography (Chinese Edition) 19 (1): 65-72 (in Chinese with English abstract).

Feng, Z.Z. 2017. A successful symposium of "multi-origin of soft-sediment deformation structures and seismites". Journal of Palaeogeography (Chinese Edition) 19 (1): 1-6 (in Chinese with English abstract).

Feng, Z.Z., Z.D. Bao, X.J. Zheng, and Y. Wang. 2017. Researches of softsediment deformation structures and seismites in China: A brief review. Journal of Palaeogeography (Chinese Edition) 19 (1): 7-12 (in Chinese with English abstract).

Friese, N., A. Vollbrecht, B. Leiss, and O. Jacke. 2011. Cambrian sedimentary dykes in the Proterozoic basement of the Västervik area (Southeast Sweden): Episodic formation inferred from macro- and microfabrics. International Journal of Earth Sciences 100 (4): 741-752.

Ge, R.F., Q.L. Zhang, L.S. Wang, G.A. Xie, S.Y. Xu, J. Chen, and X.Y. Wang. 2010. Tectonic evolution of Songliao Basin and the prominent tectonic regime transition in eastern China. Geological Review 56 (2): 180-195 (in Chinese with English abstract).

Gibert, L., P. Alfaro, F.J. Garcia-Tortosa, and G. Scott. 2011. Superposed deformed beds produced by single earthquakes (Tecopa Basin, California): Insights into paleoseismology. Sedimentary Geology 235 (3-4SI): 148-159.

Glennie, K., and A. Hurst. 2007. Fluidization and associated soft-sediment deformation in eolian sandstones: Hopeman sandstone (Permian), Scotland, and Rotliegend, North Sea. In Sand Injectites: Implications for hydrocarbon exploration and production, AAPG memoir, ed. A. Hurst and J. Cartwright, vol. 87, 245-252.

Greb, S.F., and A.W. Archer. 2007. Soft-sediment deformation produced by tides in a meizoseismic area, Turnagain arm, Alaska. Geology 35 (5): 435-438.

Grippa, A., A. Hurst, G. Palladino, D. lacopini, I. Lecomte, and M. Huuse. 2019. Seismic imaging of complex geometry: Forward modeling of sandstone intrusions. Earth and Planetary Science Letters 513: 51-63.

Guo, W.J., S.L. Chen, and J. Liu. 2007. Quaternary Holocene stratigraphy in Siping-Shuangliao area in the south margin of Song-Liao Basin. Geology and Resources 16 (1): 7-11 (in Chinese with English abstract).

Han, J.T., Z.Y. Guo, W.Y. Liu, H.S. Hou, G.X. Liu, S. Han, L.J. Liu, and T.Q. Wang. 2018. Deep dynamic process of lithosphere thinning in Songliao Basin. Chinese Journal of Geophysics 61 (6): 2265-2279 (in Chinese with English abstract).

Harris, C., J. Murton, and M.C.R. Davies. 2000. Soft-sediment deformation during thawing of ice-rich frozen soils: Results of scaled centrifuge modelling experiments. Sedimentology 47 (3): 687-700.

He, W.H., Y.Q. Zhen, Z. Chen, J. Wu, Q. Diao, H.Q. Han, Y. Bao, J. Zhou, W. Yang, P.Y. Wang, H.W. Zhang, J.F. Wu, and X.F. Sun. 2011. Three-layer tectonic framework and deep oil reservoir prospecting in the Songliao Basin. Geological Survey and Research 34 (3): 228-240 (in Chinese with English abstract).

Hilbert-Wolf, H.L., E.M. Roberts, and E.L. Simpson. 2016. New sedimentary structures in seismites from SW Tanzania: Evaluating gas- vs. waterescape mechanisms of soft-sediment deformation. Sedimentary Geology 344: 253-262.

Hurst, A., and M. Vigorito. 2017. Saucer-shaped sandstone intrusions: An underplayed reservoir target. AAPG Bulletin 101 (4): 625-633.

Ishihara, K. (1985). Stability of natural soil deposits during earthquakes, Proc. of the 11th Int. Conf. on Soil Mechanics and Foundation Engineering, San Francisco, A. A. Balkema, Rotterdam/Boston, 1, 321-376.

Kanıbir, A., R. Ulusay, and Ö. Aydan. 2006. Assessment of liquefaction and lateral spreading on the shore of Lake Sapanca during the Kocaeli (Turkey) earthquake. Engineering Geology 83 (4): 307-331.

Kholodov, V.N. 2002. Mud volcanoes, their distribution regularities and genesis: Communication 1. Mud volcanic provinces and morphology of mud volcanoes. Lithology and Mineral Resources 37 (3): 197-209.
Ko, K., S.W. Kim, H.J. Lee, I.G. Hwang, B.C. Kim, W.S. Kee, Y.S. Kim, and Y.S. Gihm. 2017. Soft sediment deformation structures in a lacustrine sedimentary succession induced by volcano-tectonic activities: An example from the cretaceous Beolgeumri formation, Wido Volcanics, Korea. Sedimentary Geology 358: 197-209.

Koç-Taşgın, C., and C. Diniz-Akarca. 2018. Soft-sediment deformation structures related to tectonomagmatic activity: A case study from the borate-bearing lacustrine deposits of early Miocene Bigadiç Basin, NW Turkey. Sedimentary Geology 373: 32-47.

Kundu, A., A. Matin, M. Mukul, and P.G. Eriksson. 2011. Sedimentary facies and soft-sediment deformation structures in the late Miocene-Pliocene middle Siwalik subgroup, eastern Himalaya, Darjiling District, India. Journal of the Geological Society of India 78 (4): 321-336.

Kuribayashi, E., and F. Tatsuoka. 1975. Brief review of liquefaction during earthquakes in Japan. Soils and Foundations 15 (4): 81-92.

Li, J., and Q.C. Wang. 2018. Relocation and focal mechanism of the Songyuan earthquake swarm sequence in 2013. Earthquake 38 (4): 6273 (in Chinese with English abstract).

Li, Y., J. Craven, E.S. Schweig, and S.S. Obermeier. 1996. Sand boils induced by the 1993 Mississippi River flood: Could they one day be misinterpreted as earthquake-induced liquefaction? Geology 24: 171-174.

Li, Y., Z.F. Shao, C. Mao, Y.P. Yang, and S.X. Liu. 2013. The seismic induced soft sediment deformation structures in the Middle Jurassic of western Qaidamu Basin. Acta Geologica Sinica - English Edition 87 (4): 979-988.

Liu, J.Q., C. Liu, J.S. Lei, W.J. Gan, Q.F. Yang, and C.X. Zhang. 2017a. The moment tensors of the 2013 Qianguo MS5.8 seismic swarm. Chinese Journal of Geophysics 60 (9): 3418-3431.

Liu, Q.F., J. Sheng, T. Lu, H.Y. Zhang, and X.D. Pan. 2017b. Research status of Fuyu/Songyuan-Zhaodong fault. Journal of Institute of Disaster Prevention 19 (3): 8-16 (in Chinese with English abstract).

Lowe, D.R. 1975. Water escape structures in coarse-grained sediments. Sedimentology 22 (2): 157-204.

Lowe, D.R. 1976. Subaqueous liquefied and fluidized sediment flows and their deposits. Sedimentology 23 (3): 285-308.

Lowe, D.R. 1983. Restricted shallow-water sedimentation of Early Archean stromatolitic and evaporitic strata of the Strelley Pool Chert, Pilbara block, Western Australia. Precambrian Research 19 (3): 239-283.

Lowe, D.R., and R.D. LoPiccolo. 1974. The characteristics and origins of dish and pillar structures. Journal of Sedimentary Petrology 44 (2): 484-501.

Lu, H.B., Y.X. Zhang, Q.L. Zhang, and J.F. Xiao. 2006. Earthquake-related tectonic deformation of soft-sediments and its constraints on basin tectonic evolution. Acta Geologica Sinica - English Edition 80 (5): 724-732.

Lu, R.J. 1981. China earthquake intensity scale (1980). Seismic Engineering Dynamics: 48-50 (in Chinese).

Mahaney, W.C., M.W. Milner, D.I. Netoff, D. Malloch, J.M. Dohm, V.R. Baker, H. Miyamoto, T.M. Hare, and G. Komatsu. 2004. Ancient wet aeolian environments on earth: Clues to presence of fossil/live microorganisms on Mars. Icarus 171 (1): 39-53.

Martín-Chivelet, J., R.M. Palma, J. López-Gómez, and D.A. Kietzmann. 2011. Earthquake-induced soft-sediment deformation structures in Upper Jurassic open-marine microbialites (Neuquén Basin, Argentina). Sedimentary Geology 235 (3): 210-221.

Massari, F., G. Ghibaudo, A. D'Alessandro, and E. Davaud. 2001. Waterupwelling pipes and soft-sediment-deformation structures in lower Pleistocene calcarenites (Salento, southern Italy). GSA Bulletin 113 (5): 545-560.

Mazumder, R., A.J. van Loon, and M. Arima. 2006. Soft-sediment deformation structures in the Earth's oldest seismites. Sedimentary Geology 186: 19-26.

Mazumder, R., A.J. van Loon, V.P. Malviya, M. Arima, and Y. Ogawa. 2016. Soft-sediment deformation structures in the Mio-Pliocene Misaki formation within alternating deep-sea clays and volcanic ashes (Miura peninsula, Japan). Sedimentary Geology 344: 323-335.

Mei, M.X., J.H. Gao, Q.F. Meng, and Z.R. Liu. 2009. Microbial mat-related silty dykes of the Precambrian: An example from the Paleoproterozoic Chuanlinggou formation at Jixian section in Tianjin. Journal of Palaeogeography (Chinese Edition) 11 (1): 37-50 (in Chinese with English abstract). 
Meng, Y.L., A.W. Hu, D.W. Qiao, X.N. Xie, X.M. Pan, J.W. Wang, and W.Z. Tian. 2012. Regional diagenetic law and control of diagenesis over gasbearing capacity of tight reservoirs in deep Xujiaweizi fault depression, Songliao Basin. Acta Geologica Sinica 86 (2): 325-334 (in Chinese with English abstract).

Miyakawa, K., T. Tokiwa, and H. Murakami. 2013. The origin of muddy sand sediments associated with mud volcanism in the Horonobe area of northern Hokkaido, Japan. Geochemistry, Geophysics, Geosystems 14 (12): 4980-4988.

Moretti, M., P. Alfaro, O. Caselles, and J.A. Canas. 1999. Modelling seismites with a digital shaking table. Tectonophysics 304 (4): 369-383.

Moretti, M., P. Alfaro, and G. Owen. 2016. The environmental significance of soft-sediment deformation structures: Key signatures for sedimentary and tectonic processes. Sedimentary Geology 344: 1-4.

Moretti, M., and A. Ronchi. 2011. Liquefaction features interpreted as seismites in the Pleistocene fluvio-lacustrine deposits of the Neuquén Basin (northern Patagonia). Sedimentary Geology 235 (3): 200-209.

Moretti, M., and L. Sabato. 2007. Recognition of trigger mechanisms for softsediment deformation in the Pleistocene lacustrine deposits of the Sant'Arcangelo Basin (southern Italy): Seismic shock vs. overloading. Sedimentary Geology 196: 31-45.

Moretti, M., J.M. Soria, P. Alfaro, and N. Walsh. 2001. Asymmetrical soft-sediment deformation structures triggered by rapid sedimentation in turbiditic deposits (late Miocene, Guadix Basin, southern Spain). Facies 44 (1): 283-294.

Mount, J.F. 1993. Formation of fluidization pipes during liquefaction: Examples from the Uratanna formation (Lower Cambrian), South Australia. Sedimentology 40 (6): 1027-1037.

Murton, J.B., P. Worsley, and J. Gozdzik. 2000. Sand veins and wedges in cold aeolian environments. Quaternary Science Reviews 19 (9): 899-922.

Nichols, R.J., R.S.J. Sparks, and C.J.N. Wilson. 1994. Experimental studies of the fluidization of layered sediments and the formation of fluid escape structures. Sedimentology 41 (2): 233-253.

Obermeier, S.F. 1996. Use of liquefaction-induced features for paleoseismic analysis - An overview of how seismic liquefaction features can be distinguished from other features and how their regional distribution and properties of source sediment can be used to infer the location and strength of Holocene paleo-earthquakes. Engineering Geology 44: 1-76.

Obermeier, S.F., and S.E. Dickenson. 2000. Liquefaction evidence for the strength of ground motions resulting from late Holocene Cascadia subduction earthquakes, with emphasis on the event of 1700 a.D. Seismological Society of America 90 (4): 876-896.

Obermeier, S.F., P.J. Munson, C.A. Munson, J.R. Martin, A.D. Frankel, T.L. Youd, and E.C. Pond. 1992. Liquefaction evidence for strong Holocene earthquake(s) in the Wabash Valley of Indiana-Illinois. Seismological Research Letters 63 (3): 321-335.

Obermeier, S.F., and E.C. Pond. 1999. Issues in using liquefaction features for paleoseismic analysis. Seismological Research Letters 70: 34-58.

Oppo, D., and R. Capozzi. 2016. Spatial association of mud volcano and sandstone intrusions, Boyadag anticline, western Turkmenistan. Basin Research 28 (6): 827-839.

Owen, G. 1987. Deformation processes in unconsolidated sands. Geological Society, London, Special Publications 29: 11-24.

Owen, G. 1995. Soft-sediment deformation in Upper Proterozoic Torridonian sandstones (Applecross formation) at Torridon, Northwest Scotland. Journal of Sedimentary Research 65 (3a): 495-504.

Owen, G. 1996. Anatomy of a water-escape cusp in Upper Proterozoic Torridon group sandstones, Scotland. Sedimentary Geology 103 (1-2): 117-128.

Owen, G. 2003. Load structures: Gravity-driven sediment mobilization in the shallow subsurface. Geological Society, London, Special Publications 216: 21-34.

Owen, G., and M. Moretti. 2008. Determining the origin of soft-sediment deformation structures: A case study from Upper Carboniferous delta deposits in south-west Wales, UK. Terra Nova 20 (3): 237-245.

Owen, G., and M. Moretti. 2011. Identifying triggers for liquefaction-induced soft-sediment deformation in sands. Sedimentary Geology 235 (3-4SI): 141-147.

Owen, G., M. Moretti, and P. Alfaro. 2011. Recognising triggers for softsediment deformation: Current understanding and future directions. Sedimentary Geology 235 (3-4SI): 133-140.
Owen, G., and M.G.M. Santos. 2014. Soft-sediment deformation in a prevegetation river system: The Neoproterozoic Torridonian of NW Scotland. Proceedings of the Geologists' Association 125: 511-523.

Pan, X.D., R. Jia, J.H. Kang, and B.B. Liu. 2018. Research on Qianguo M5.8 earthquake swarm on October 31, 2013. Recent Developments in World Seismology (4): 80-89 (in Chinese with English abstract).

Phillips, E., J. Everest, and H. Rrrves. 2013. Micromorphological evidence for subglacial multiphase sedimentation and deformation during overpressurized fluid flow associated with hydrofracturing. Boreas 42: 395-427.

Pisarska-Jamroży, M., A.J. van Loon, M. Mleczak, and M. Roman. 2019. Enigmatic gravity-flow deposits at Ujście (western Poland), triggered by earthquakes (as evidenced by seismites) caused by Saalian glacioisostatic crustal rebound. Geomorphology 326: 239-251.

Ravier, E., J. Buoncristiani, J. Menzies, M. Guiraud, and E. Portier. 2015. Clastic injection dynamics during ice front oscillations: A case example from Sólheimajökull (Iceland). Sedimentary Geology 323: 92-109.

Rodríguez-Pascua, M.A., J.P. Calvo, G. De Vicente, and D. Gómez-Gras. 2000 Soft-sediment deformation structures interpreted as seismites in lacustrine sediments of the Prebetic zone, SE Spain, and their potential use as indicators of earthquake magnitudes during the late Miocene. Sedimentary Geology 135 (1): 117-135.

Rodríguez-Pascua, M.A., P.G. Silva, R. Pérez-López, J.L. Giner-Robles, F. MartínGonzález, and B. Del Moral. 2015. Polygenetic sand volcanoes: On the features of liquefaction processes generated by a single event (2012 Emilia Romagna 5.9 Mw earthquake, Italy). Quaternary International 357: 329-335.

Ross, J.A., J. Peakall, and G.M. Keevil. 2011. An integrated model of extrusive sand injectites in cohesionless sediments. Sedimentology 58 (7): 16931715.

Rowe, C. 2013. Shaking loose: Sand volcanoes and Jurassic earthquakes. Geology 41 (10): 1135-1136.

Satur, N., and A. Hurst. 2007. Sand-injection structures in deep-water sandstones from the ty formation (Paleocene), Sleipner st field, Norwegian North Sea. In Sand Injectites: Implications for hydrocarbon exploration and production, AAPG memoir, ed. A. Hurst and J. Cartwright, vol. 87, 113-117.

Shanmugam, G. 2016. The seismite problem. Journal of Palaeogeography 5 (4): $318-362$.

Shanmugam, G. 2017. Global case studies of soft-sediment deformation structures (SSDS): Definitions, classifications, advances, origins, and problems. Journal of Palaeogeography 6 (4): 251-320.

Shao, B., J. Shen, Y.Z. Li, X.H. Yu, X.Y. Dai, J.F. Yuan, and Y. Yu. 2015. Quantitative seismic risk evaluation on blind Gudian fault in Jilin Province on petroleum geological and historical seismic data. Earthquake Research in China 31 (4): 668-678 (in Chinese with English abstract).

Shao, Z.F., J.H. Zhong, L.H. Fan, Y. Li, B. Liu, Z.Q. Li, K. Luo, and S.J. Wang 2014a. Characteristics and petroleum geologic significance of seismites in the member 3 of Shahejie formation in south section of western sag, Liaohe depression. Acta Petrolei Sinica 35 (3): 439-449 (in Chinese with English abstract).

Shao, Z.F., J.H. Zhong, Y. Li, C. Mao, S.X. Liu, L.T. Ni, Y. Tian, X.Y. Cui, Y.T. Liu, X.N. Wang, W.H. Li, and G.S. Lin. 2014b. Characteristics and sedimentary processes of lamina-controlled sand-particle imbricate structure in deposits on Lingshan Island, Qingdao, China. Science China Earth Sciences 57 (5): 1061-1076.

Shao, Z.F., J.H. Zhong, Y. Li, L.T. Ni, S.X. Liu, L.H. Fan, and B. Chen. 2014c. The sedimentary characteristics and environmental analysis of late Mesozoic gravity flows in Lingshan Island. Geological Review 60 (3): 555-566 (in Chinese with English abstract).

Shi, G.R., Y.S. Du, and Y.M. Gong. 2007. Soft-sediment deformation structures interpreted as seismite from the Middle Permian of the southern Sydney Basin, southeastern Australia. Australian Journal of Earth Sciences 54 (6): 861-874.

Su, D.C., X.F. Qiao, A.P. Sun, H.B. Li, and I.D. Somerville. 2014. Large earthquake-triggered liquefaction mounds and a carbonate sand 
volcano in the Mesoproterozoic Wumishan formation, Beijing, North China. Geological Journal 49 (1): 69-89.

Su, D.C., Z.B. Yang, A.P. Sun, and X.F. Qiao. 2019. Discovery of the Jurassic seismic liquefaction sandstone pipes in the Yungang grottoes, Shanxi province and its tectonic significance. Acta Geologica Sinica 93 (8): 1814-1830 (in Chinese with English abstract).

Takahama, N., T. Otsuka, and B. Brahmantyo. 2000. A new phenomenon in ancient liquefaction - The draw-in process, its final stage. Sedimentary Geology 135: 157-165.

Tian, H., X.D. Guo, Q. Liu, and W.Q. Zhang. 2011. Matsubara City of groundwater dynamics and environmental issues. Groundwater 33 (6): 45-46 (in Chinese with English abstract).

Tian, H.S., B.H. Zhang, S.H. Zhang, and M.Y. Lü. 2014. Neogene seismites and seismic volcanic rocks in the Linqu area, Shandong Province, E China. Geologos 20 (2): 125-137.

Topal, S., and M. Özkul. 2014. Soft-sediment deformation structures interpreted as seismites in the Kolankaya formation, Denizli Basin (SW Turkey). The Scientific World Journal 2014 (352654): 1-13. https://doi.org/ $10.1155 / 2014 / 352654$.

Tuttle, M.P. 2001. The use of liquefaction features in paleoseismology: Lessons learned in the New Madrid seismic zone, Central United States. Journal of Seismology 5 (3): 361-380.

Ulvrova, M., R. Paris, P. Nomikou, K. Kelfoun, S. Leibrandt, D.R. Tappin, and F. W. McCoy. 2016. Source of the tsunami generated by the 1650 AD eruption of Kolumbo submarine volcano (Aegean Sea, Greece). Journal of Volcanology and Geothermal Research 321: 125-139.

Valente, A., A. Ślączka, and G. Cavuoto. 2014. Soft-sediment deformation structures in seismically affected deep-sea Miocene turbidites (Cilento Basin, southern Italy). Geologos 20 (2): 67-78.

van Loon, A.J. 2009. Soft-sediment deformation structures in siliciclastic sediments: An overview. Geologos 15 (1): 3-55.

van Loon, A.J., and P. Maulik. 2011. Abraded sand volcanoes as a tool for recognizing paleo-earthquakes, with examples from the Cisuralian Talchir formation near Angul (Orissa, eastern India). Sedimentary Geology 238 (1-2): 145-155.

Wang, C., M. Manga, and A. Wong. 2005. Floods on Mars released from groundwater by impact. Icarus 175 (2): 551-555.

Wang, L., J. Li, Q.Q. Gu, and R.M. He. 2015a. Accurate relocation of earthquake swarm in Songyuan, Jilin, China. Journal of Disaster Prevention and Reduction 31 (1): 30-34 (in Chinese with English abstract).

Wang, P.J., R.L. Zhao, Q.A. Meng, X.J. Qu, D.F. Zhu, and Y.F. Gao. 2015b. The cretaceous Songliao Basin: Dynamic background from volcanic rift to interior sag basin. Earth Science Frontiers 22 (3): 99-117 (in Chinese with English abstract)

Wei, M.X., X.M. Hao, H. Lv, M.X. Zhou, and C. Yu. 2016. Sand liquefaction disaster research of 2013 M 5.8 Qianguo earthquake swarm based on GIS. Journal of Disaster Prevention and Reduction 32 (3): 64-69 (in Chinese with English abstract).

Wu, G. 1991. The study and the analysis of historical earthquake material in north-East China. Northeastern Seismological Research 7 (1): 17-24 (in Chinese with English abstract).

Xue, Y., X.W. Zeng, G.P. Liu, and H.L. Cai. 2015. Study on the 2013 Qianguo Ms5.8 earthquake swarm sequence, Jilin, China. Earthquake Research in China 31 (3): 481-491 (in Chinese with English abstract).

Yamaguchi, A., T. Mori, M. Kazama, and N. Yoshida. 2012. Liquefaction in Tohoku district during the 2011 off the Pacific coast of Tohoku earthquake. Soils and Foundations 52 (5): 811-829.

Yang, C.X. 1985. The characteristics of sand vein and sand volcano and their importance to earthquake. Northwestern Seismological Journal 7 (2): 99-103.

Yang, Q.F., J.L. Wang, Z.P. Liu, Z.Y. Wu, and B. Chen. 2010. Geological features and quaternary activity of the second Songhua River fault Earthquake Research in China 26 (1): 34-45 (in Chinese with English abstract).

Yi, X.F., C.M. Zhang, S.H. Li, J.Y. Du, K. Li, H.Y. Wang, X.Y. Li, F.J. Zhou, and C. Yuan. 2015. Sand injectite simulation and formation mechanism analysis. Journal of Palaeogeography (Chinese Edition) 17 (5): 669-676 (in Chinese with English abstract).

Zhang, G.C., H.F. Liu, and D.F. Zhu. 1997. Late Mesozoic rifting and extensional structural pattern in Songliao Basin. Xinjiang Petroleum Geology 18 (1): 30-34 (in Chinese with English abstract).

Zhao, F.Y. 2010. A study of the regularity of quaternary geological history evolution in Songliao plain based on geological remote sensing survey. Remote Sensing for Land and Resources 22 (1): 152-158 (in Chinese with English abstract).

Zhao, Q.Y. 2012. Effect of groundwater and cover on sand liquefaction. West China Exploration Engineering 1: 8-12 (in Chinese with English abstract).

Zhong, J.H., M.C. Cao, L.T. Ni, N.L. Sun, C. Liu, B. Hao, G.Q. Yang, G.X. Song, and Y.Z. Ge. 2018. Situation of study and development tendency of sandy dykes. Journal of Palaeogeography (Chinese Edition) 20 (1): 119132 (in Chinese with English abstract).

Zhong, J.H., and G. Liang. 2009. Situation of study and development tendency of sedimentary structure. Geological Review 55 (6): 831-839 (in Chinese with English abstract).

Zhong, J.H., H.Q. Wang, Y. Li, Y. Wang, and Z.F. Wen. 2006. Ice-water pits upon the Yellow River delta plain. Sedimentary Geology 187 (1-2): 1-10.

Zhong, J.H., S.H. Xu, Z.K. Wang, H.Q. Wang, F. Ma, H.L. Duan, A. Abdurahman, J. Zhou, Y.T. Liu, and Y. Li. 2008. Study on the Quarternary glacial-ploughed deformation beddings in seven springs area, western Qaidam Basin. Geological Review 54 (2): 207-214 (in Chinese with English abstract).

\section{Publisher's Note}

Springer Nature remains neutral with regard to jurisdictional claims in published maps and institutional affiliations.

\section{Submit your manuscript to a SpringerOpen ${ }^{\circ}$ journal and benefit from:}

- Convenient online submission

- Rigorous peer review

- Open access: articles freely available online

- High visibility within the field

- Retaining the copyright to your article

Submit your next manuscript at $\boldsymbol{\nabla}$ springeropen.com 